\title{
On the observation of unusual high concentration of small chain-like aggregate ice crystals and large ice water contents near the top of a deep convective cloud during the CIRCLE-2 experiment
}

\author{
J.-F. Gayet ${ }^{1}$, G. Mioche ${ }^{1}$, L. Bugliaro ${ }^{2}$, A. Protat ${ }^{3}$, A. Minikin ${ }^{2}$, M. Wirth ${ }^{2}$, A. Dörnbrack ${ }^{2}$, V. Shcherbakov ${ }^{1,4}$, \\ B. Mayer $^{2}$, A. Garnier ${ }^{3}$, and C. Gourbeyre ${ }^{1}$ \\ ${ }^{1}$ Laboratoire de Météorologie Physique, UMR6016 CNRS/Université Blaise Pascal, Clermont-Ferrand, France \\ ${ }^{2}$ Institut für Physik der Atmosphäre, Deutsches Zentrum für Luft- und Raumfahrt (DLR), Oberpfaffenhofen, Germany \\ ${ }^{3}$ Laboratoire Atmosphères, Milieux, Observations Spatiales, UMR8190 CNRS/Université Pierre et Marie Curie, France \\ ${ }^{4}$ Laboratoire de météorologie Physique, Institut Universitaire de Technologie de Montluçon, Montluçon, France
}

Correspondence to: J.-F. Gayet (j.f.gayet@opgc.univ-bpclermont.fr)

Received: 15 July 2011 - Published in Atmos. Chem. Phys. Discuss.: 25 August 2011

Revised: 1 December 2011 - Accepted: 30 December 2011 - Published: 16 January 2012

\begin{abstract}
During the CIRCLE-2 experiment carried out over Western Europe in May 2007, combined in situ and remote sensing observations allowed to describe microphysical and optical properties near-top of an overshooting convective cloud $\left(11080 \mathrm{~m} /-58^{\circ} \mathrm{C}\right)$. The airborne measurements were performed with the DLR Falcon aircraft specially equipped with a unique set of instruments for the extensive in situ cloud measurements of microphysical and optical properties (Polar Nephelometer, FSSP-300, Cloud Particle Imager and PMS 2-D-C) and nadir looking remote sensing observations (DLR WALES Lidar). Quasi-simultaneous space observations from MSG/SEVIRI, CALIPSO/CALIOP-WFC-IIR and CloudSat/CPR combined with airborne RASTA radar reflectivity from the French Falcon aircraft flying above the DLR Falcon depict very well convective cells which overshoot by up to $600 \mathrm{~m}$ the tropopause level. Unusual high values of the concentration of small ice particles, extinction, ice water content (up to $70 \mathrm{~cm}^{-3}, 30 \mathrm{~km}^{-1}$ and $0.5 \mathrm{~g} \mathrm{~m}^{-3}$, respectively) are experienced. The mean effective diameter and the maximum particle size are $43 \mu \mathrm{m}$ and about $300 \mu \mathrm{m}$, respectively. This very dense cloud causes a strong attenuation of the WALES and CALIOP lidar returns. The SEVIRI retrieved parameters confirm the occurrence of small ice crystals at the top of the convective cell. Smooth and featureless phase functions with asymmetry factors of 0.776 indicate fairly uniform optical properties. Due to small ice crystals the power-law relationship between ice water content (IWC) and radar reflectivity appears to be very different from those usually found in cirrus and anvil clouds. For a given equivalent reflectivity factor, IWCs are significantly larger for the overshooting cell than for the cirrus. Assuming
\end{abstract}

the same prevalent microphysical properties over the depth of the overshooting cell, RASTA reflectivity profiles scaled into ice water content show that retrieved IWC up to $1 \mathrm{~g} \mathrm{~m}^{-3}$ may be observed near the cloud top. Extrapolating the relationship for stronger convective clouds with similar ice particles, IWC up to $5 \mathrm{~g} \mathrm{~m}^{-3}$ could be experienced with reflectivity factors no larger than about $20 \mathrm{dBZ}$. This means that for similar situations, indication of rather weak radar echo does not necessarily warn the occurrence of high ice water content carried by small ice crystals. All along the cloud penetration the shape of the ice crystals is dominated by chainlike aggregates of frozen droplets. Our results confirm previous observations that the chains of ice crystals are found in a continental deep convective systems which are known generally to generate intense electric fields causing efficient ice particle aggregation processes. Vigorous updrafts could lift supercooled droplets which are frozen extremely rapidly by homogeneous nucleation near the $-37^{\circ} \mathrm{C}$ level, producing therefore high concentrations of very small ice particles at upper altitudes. They are sufficient to deplete the water vapour and suppress further nucleation as confirmed by humidity measurements. These observations address scientific issues related to the microphysical properties and structure of deep convective clouds and confirm that particles smaller than $50 \mu \mathrm{m}$ may control the radiative properties in convective-related clouds. These unusual observations may also provide some possible insights regarding engineering issues related to the failure of jet engines commonly used on commercial aircraft during flights through areas of high ice water content. However, large uncertainties of the measured and derived parameters limit our observations. 


\section{Introduction}

The size, shape and concentration of the ice crystals at the top of the ice clouds are among of the critical parameters which are important in cloud radiative forcing (see for instance Stephens et al., 1990) as well as for the reliability of remote retrieval techniques. Cloud in situ observations are one of the tools that may serve as a basis for the development of more accurate microphysical and radiation parameterizations for regional climate models. In situ observations have rarely been devoted to the description of near-top convective clouds and anvils over Western Europe. Most of the recent observations come from experiments carried out in different subtropical and Tropical regions and over the Great Plains of USA. For instance, during the extensive in situ measurements of the Central Equatorial Pacific EXperiment (CEPEX), particle concentrations measured by the 2-D probes did not exceed a few hundreds per liter and derived ice water content (IWC) values were $<0.3 \mathrm{~g} \mathrm{~m}^{-3}$ (McFarquhar and Heysmfield, 1996). FSSP-300 particle concentrations (exceeding $1 \mathrm{~cm}^{-3}$ ) were not included in the determination of the total particle concentration. High ice particle concentration have been reported by Connolly et al. (2005) during the Egret Microphysics with Extended Radiation and Lidar experiment (EMERALD-II) in outflow cirrus from Tropical multi-cell storms near Darwin. During the SCOUTAMMA campaign over West Africa in August 2006, Frey et al. (2011) reported measurements in a young mesoscale convective system (MCS) outflow with ice crystal concentrations of up to $8.3 \mathrm{~cm}^{-3}$, rimed ice particles with maximum dimensions exceeding $1.5 \mathrm{~mm}$ and a maximum ice water content of $0.05 \mathrm{~g} \mathrm{~m}^{-3}$. The data collected during the Tropical Composition, Cloud, and Climate Coupling (TC4) and the NASA African Monsoon Multidisciplinary Analyses (NAMMA) campaigns with a new 2-D-S probe (an optical imaging probe with improved response characteristics, Lawson et al., 2006a) report that small ice crystal rarely make a significant contribution to cloud extinction and optical depth (Lawson et al., 2010). Other observations are contrary to the above results which rather suggest that small ice crystals play a dominant role in governing the radiative properties of cirrus anvils (Garrett et al., 2003; Fridlind et al., 2004; Davis et al., 2009). Controversy remains over whether the high ice crystal concentrations are real or an artefact, particularly in conditions with lots of large ice crystals (Heymsfield and Miloshevich, 1995). For instance Jensen et al. (2009) suggest that previous measurements of ice crystal concentration in anvil cirrus have often been hampered by ice particle shattering on probe tips.

Previous measurements addressed mostly the anvil part of the convective systems outside updraft regions, which remain poorly documented with accurate measurements. Strapp et al. (1999) found maximum ice water contents in excess of $1.3 \mathrm{~g} \mathrm{~m}^{-3}$, and often sustained ice water contents in excess of $0.5 \mathrm{~g} \mathrm{~m}^{-3}$. Abraham et al. (2004) reported a broad area in extratropical cyclones that were higher than $1 \mathrm{~g} \mathrm{~m}^{-3}$. The ice water content values in these two papers are probably underestimates given what is now known about the performance of the standard Nevzorov LWC/TWC probe (Korolev et al., 2008). IWC from 1.5 to $2.5 \mathrm{~g} \mathrm{~m}^{-3}$ were reported in intense mid-latitude storms over the Great Plains of USA (Heymsfield and Palmer, 1986; Lawson et al., 1998). Likewise in Tropical convective turrets clouds, ice water content exceeding $2 \mathrm{~g} \mathrm{~m}^{-3}$ and extinction up to $60 \mathrm{~km}^{-1}$ have been measured (Lawson et al., 2010). An early Royal Aircraft Establishment report by McNaughton (1959), which has been used for years to provide some guidelines to aviation on ice water content, describes measurements made in convective clouds near Entebbe, Singapore and Darwin with total water contents (probably mostly ice) exceeding $5 \mathrm{~g} \mathrm{~m}^{-3}$. Mazzawy and Strapp (2007) summarize these and other measurements in order to come up with "Appendix D - An Interim Icing Envelope" which defines a mixed phase/glaciated icing environment to be used by the aviation industry in certifying engines for operations in these conditions.

Early airborne measurements (Heymsfield, 1986) of cirrus from deep convection have shown that ice-crystal aggregation may be important at temperatures below $-50^{\circ} \mathrm{C}$. Crystal habit distributions in the anvil cirrus outflows of thunderstorms in general contain typically both compact or platelike in maritime situations and a mixture of irregular crystals what appear to be aggregated plates in continental situations (Lawson et al., 2003). The measurements by Stith et al. (2002) have highlighted that ice-crystal aggregates are present only at lower temperatures (approximately $-43^{\circ} \mathrm{C}$ ). By comparing chains of ice crystals observed in clouds with previous laboratory experiments, Connolly et al. (2005) hypothesized that the ice particle aggregation processes are caused by intense electric fields.

In this paper we describe combined in situ and remote sensing observations for the characterization of the microphysical and optical properties near the top of an overshooting convective cell. The in situ measurements reveal unusual high concentration of small chain-like aggregate ice crystals and large ice water content and extinction. These observations were obtained on 26 May 2007 over Germany during the coordinated German-French CIRrus CLoud Experiment (CIRCLE-2, Eichler et al., 2009). The objectives of this campaign were devoted to a better understanding of the processes involved in cirrus cloud life cycles, and to the validation of satellite observations (CALIPSO/CALIOP and CloudSat/CPR). Section 2 presents the field campaign and the aircraft and remote sensing measurements that are discussed in this paper. Section 3 discusses the combined remote sensing observations (satellite and airborne data) and cloud in situ measurements related to the description of the properties of the convective cell which overshoots the tropopause. Section 4 gives a detailed description of the microphysical and optical properties of the cloud with implications regarding the ice water content - equivalent reflectivity 
factor (IWC-Z) relationship. Finally, Sect. 5 gives an interpretation of the observations. Scientific issues related to the microphysical properties and structure of deep convective clouds are discussed with some possible insights regarding engineering issues related to the flights of commercial aircraft through areas of high ice water content (e.g. Lawson et al., 1998; Strapp et al., 1999 and Mason et al., 2006).

\section{Field campaign and measurements}

\subsection{The CIRCLE-2 experiment}

The CIRCLE-2 campaign and the satellite and aircraft colocation strategy were already described in detail (Mioche et al., 2010a). We recall that this campaign (held from 4 to 26 May 2007) involved two Falcon aircraft. The German Falcon operated by DLR (Deutsches Zentrum für Luft- und Raumfahrt) was equipped with microphysical and optical in situ probes and with the DLR WALES Lidar (Water Vapour Lidar Experiment in Space, Wirth et al., 2009). The French Falcon operated by SAFIRE (Service des Avions Français Instrumentés pour la Recherche en Environnement), was carrying remote sensing down-looking from the Radar-Lidar (RALI) system (Protat et al., 2004). The two aircraft were operated from Oberpfaffenhofen (near Munich, Germany) and from Creil (near Paris, France), respectively.

The two Falcon aircraft were co-ordinated to fly under CloudSat-CALIPSO tracks according to the cirrus cloud forecasts based on the European Centre of Medium Range Weather Forecasts (ECMWF) over Western Europe provided by DLR. On both aircraft, the altitude and position parameters were measured by the airborne GPS systems with an accuracy of $50 \mathrm{~m}$. This allowed us to accurately follow the satellite track for reliable comparisons and to get an accurate altitude reference for all observations. The DLR Falcon flight plan consisted of several in-cloud sequences at constant levels, first near the cloud top, and then at different lower levels depending on the cloud width. Each sequence lasted about $15 \mathrm{~min}-20 \mathrm{~min}$ (or 180-250 km long) with a U-turn manoeuvre at the end of the sequence. The SAFIRE Falcon flight plan was to fly above the cirrus layer at the maximum ceiling $(\sim 12000 \mathrm{~m})$ with nadir looking observations.

\subsection{Instrumentation and measurements aboard the DLR Falcon}

In order to characterize the cloud microphysical and optical properties four independent techniques are used in this study: (1) the PMS FSSP-300 operated by DLR, (2) the Particle Cloud Imager (CPI), (3) the PMS 2-D-C and (4) the Polar Nephelometer probes, operated by the Laboratoire de Météorologie Physique (LaMP). Thanks to the combination of these techniques, a description of particles within a range of diameters varying from a few micrometers (typically $3 \mu \mathrm{m}$ ) to about $2 \mathrm{~mm}$ is possible.
The method of data processing, the reliability of the instruments mounted on the Falcon aircraft and the uncertainties of the derived microphysical and optical parameters during CIRCLE- 2 have been described in detail by Mioche et al. (2010a). The method of bulk parameters calculations is summarized in Appendix A. The derivation of the radar equivalent reflectivity factor from the CPI data having been thoroughly detailed by Gayet et al. (2009), we only recall here that the calculations were made for CloudSat/CPR validation purposes and consider therefore the dielectric factors of ice at $94 \mathrm{GHz}$ and the ratio of Mie scattering to Rayleigh scattering at $94 \mathrm{GHz}$.

Because of some intermittent failures which occurred on the PMS 2-D-C data acquisition system, the available data are not discussed in this study but have been used to validate the CPI measurements (see Appendix B). Therefore the CPI data were used in order to derive the particle size distributions and the microphysical parameters as Gallagher et al. (2005) in cirrus clouds. The method of calibration of the CPI is described in Appendix B with some results of comparison with the 2-D-C. The overall uncertainties on derived microphysical parameters from FSSP-300 and 2-D-C/CPI instruments are $75 \%, 85 \%$ and $100 \%$ on particle concentration, extinction coefficient and ice water content, respectively (Gayet et al., 2002). The uncertainty on the radar equivalent reflectivity factor calculated from the CPI data has been evaluated to $\pm 4 \mathrm{dBZ}$ (Mioche, 2010b). These error bars include the uncertainties due to a poor statistical representation of just a few large particles that may occur in our case study. Direct measurement of the scattering phase function from the Polar Nephelometer probe allows the calculation of the extinction coefficient and asymmetry parameter with accuracies evaluated to $25 \%$ and $4 \%$, respectively (Gayet et al., 2002; Jourdan et al., 2010). The accuracies of the in situ measurements reported above could be drastically reduced by the shattering of large ice crystals on probes with shrouded inlets (Polar Nephelometer, CPI and PMS FSSP and 2-D-C for instance). Appendix $\mathrm{C}$ discusses this problem in the context of the observations presented here and gives an assessment on the reliability of the cloud measurements.

The WALES lidar (downward oriented) uses a laser operating at $1064 \mathrm{~nm}$, with parallel and orthogonal polarization detectors (Wirth et al., 2009). The vertical resolution of the derived attenuated backscatter ratio is $15 \mathrm{~m}$ and the profiles are available every $0.2 \mathrm{~s}$ ( $\sim 40 \mathrm{~m}$ horizontal resolution). The lidar blind distance is typically $200 \mathrm{~m}$.

Relative humidity was derived from measurements using a CR-2 frost point hygrometer (Buck Research Instruments, Busen and Buck, 1995). Depending on water vapor gradients, the response time of the frost point hygrometer is in the order of few seconds to one minute. The uncertainty in relative humidity with respect to ice RHi (including the temperature uncertainty $\pm 0.5 \mathrm{~K}$ ) amounts to $\pm 11 \%$. The derivation method of the vertical airspeed from the Falcon aircraft measurements has been described in Bögel and Baumann (1991). 
An error of $\pm 10 \mathrm{~cm} \mathrm{~s}^{-1}$ for a mean value within a flight path of $200 \mathrm{~km}$ (or about $20 \mathrm{~min}$ flight duration) is generally expected.

\subsection{The RASTA radar onboard the SAFIRE Falcon}

As indicated above, the French Falcon 20 was equipped with the radar-lidar (RALI) instrument. This instrument (described in details by Protat et al., 2004) is the airborne combination of two instruments: a multi-beam (three antennas pointing downward in three non-collinear directions, including one near-nadir pointing angle) $95-\mathrm{GHz}$ Doppler cloud radar named RASTA (Radar SysTem Airborne, see Bouniol et al., 2008 and Protat et al., 2009 for further details) and a triple-wavelength $(355,532$, and $1064 \mathrm{~nm})$ and dual-polarization $(532 \mathrm{~nm})$ backscatter lidar. Unfortunately, during the 26 May flight the lidar was not operational, so in this study only the Doppler cloud radar observations are used. The vertical and horizontal resolutions of the data are $60 \mathrm{~m}$ and $150 \mathrm{~m}$, respectively. The blind distance is $180 \mathrm{~m}$. The RASTA radar has been calibrated using ocean surface backscatter at $95 \mathrm{GHz}$ (Bouniol et al., 2008). The sensitivity of the airborne cloud radar during CIRCLE-2 was $-31.5 \mathrm{dBZ}$ at $1 \mathrm{~km}$ range.

\subsection{Satellite data}

In this paper we use Meteosat-9 (MET-9), CALIPSO and CloudSat observations. The MET-9 satellite's main payload is the optical scanning imaging radiometer, so-called Spinning Enhanced Visible and InfraRed Imager (SEVIRI). It provides image data in four visible and near-infrared channels $(0.4-1.6 \mu \mathrm{m})$ and eight InfraRed channels (3.9$13.4 \mu \mathrm{m})$. Sampling distances are $1 \mathrm{~km}$ for the High Resolution Visible Channel and $3 \mathrm{~km}$ for the infrared and the three other visible channels, respectively.

The payload of the CALIPSO satellite includes the CloudAerosol Lidar with Orthogonal Polarization (CALIOP), the Imaging Infrared Radiometer (IIR) and the Wide Field Camera (WFC). CALIOP is a laser operating at $532 \mathrm{~nm}$ and $1064 \mathrm{~nm}$, with parallel and orthogonal polarization detectors at $532 \mathrm{~nm}$ (Winker et al., 2003; Hunt et al., 2009). The horizontal and vertical resolutions of the attenuated backscattering coefficient product used here are $5 \mathrm{~km}$ and $60 \mathrm{~m}$, respectively. IIR is a nadir-viewing, non-scanning imaging radiometer having a $69 \mathrm{~km}$ swath with a pixel size of $1 \mathrm{~km}$ which provides measurements at three channels in the thermal infrared window region at $8.65 \mu \mathrm{m}, 10.6 \mu \mathrm{m}$, and $12.05 \mu \mathrm{m}$ with a bandpass of $0.9 \mu \mathrm{m}, 0.6 \mu \mathrm{m}$ and $1 \mu \mathrm{m}$ respectively (Winker et al., 2010). The CALIOP beam is nominally aligned with the center of the IIR image. WFC is a fixed, nadir-viewing imager with a single spectral channel covering the $620-670 \mathrm{~nm}$ region, selected to match the band 1 of the MODIS (MODerate resolution Imaging Spectroradiome-

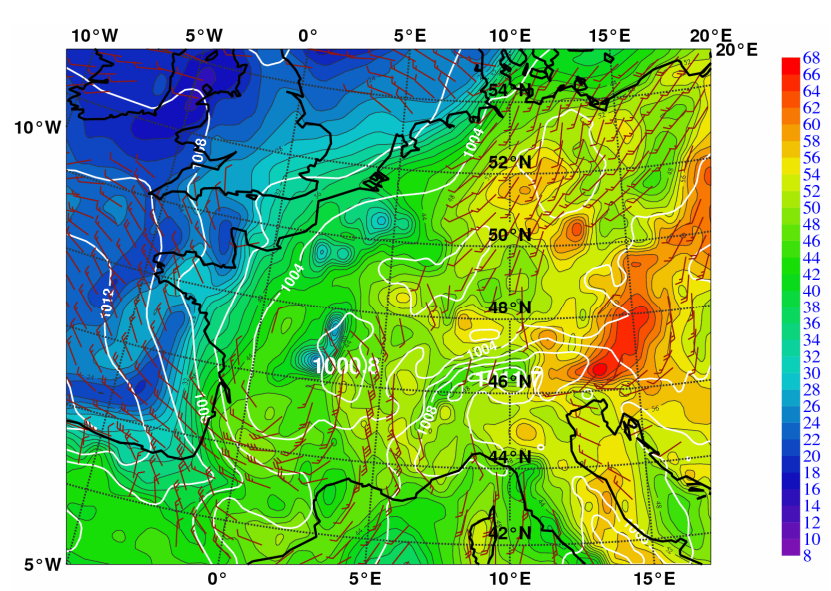

Fig. 1. Equivalent potential temperature (color shading, ${ }^{\circ} \mathrm{C}$ ), and horizontal wind (barbs) at the $850 \mathrm{hPa}$ pressure level on 26 May 2007, 12:00 UTC. White contour lines: mean sea level pressure in $\mathrm{hPa}$.

ter) instrument on NASA's Aqua satellite. The Instantaneous Field of View (IFOV)/swath is $125 \mathrm{~m} / 61 \mathrm{~km}$.

CloudSat carries a $94 \mathrm{GHz}(3.2 \mathrm{~mm})$ cloud profiling radar (CPR) to provide the vertical distribution of hydrometeors on a global scale (Stephens et al., 2002). The CPR has a nominal vertical resolution of $500 \mathrm{~m}$ and a footprint of $1.4 \times 1.7 \mathrm{~km}^{2}$ (cross and along track) for a CPR profile. The CIRCLE-2 observations gathered by RASTA under the CloudSat track have allowed a through validation of the calibration of the CloudSat radar (Protat et al., 2009) using common samples of ocean surface returns and ice cloud reflectivities. An agreement within $1 \mathrm{~dB}$ has been reached between RASTA and CloudSat.

\subsection{Weather situation}

As mentioned above the first part of the research flight on 26 May 2007 consisted of several sequences at different levels with quasi-collocated trajectories with the CALIPSO overpass (12:32 UT) in the surrounding cirrus of the convective system (Mioche et al., 2010a). According to the ECMWF operational analyses, warm and humid air (see the high equivalent potential temperature in Fig. 1) originating from the Mediterranean had been advected over the Alps. This unstable air mass preceded a slowly eastward propagating trough which was situated over France. Vertical profiles of air temperature and dew-point temperature were measured by the Falcon aircraft during the descent sequence at the end of the flight (13:10-13:54 UT), see Fig. 2a. These profiles indicate an unstable layer extending from about $2700 \mathrm{~m}\left(7^{\circ} \mathrm{C}\right.$ at the cloud base) up to about $10700 \mathrm{~m}$ altitude $\left(-56^{\circ} \mathrm{C}\right.$ at the tropopause). The vertically unstable stratification in the warm sector of the approaching cold front favoured the development of deep convective clouds already in the morning hours of this day. Figure $2 \mathrm{~b}$ displays the theoretical adiabatic 


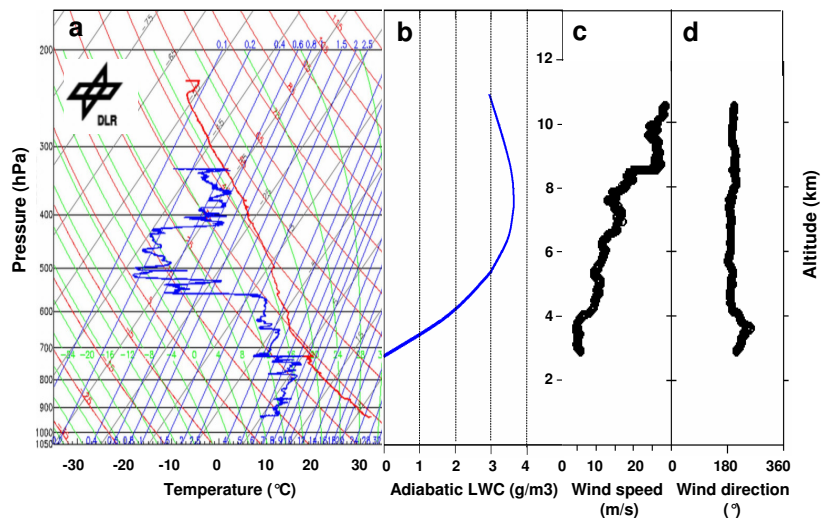

Fig. 2. Vertical profiles of (a): temperature and Dew-point measured by the Falcon; (b): theoretical adiabatic liquid water content (LWC); (c) and (d): wind speed and direction components, respectively.

liquid water content (LWC) assuming the thermodynamic properties of the cloud base as indicated above. A maximum adiabatic LWC of $3.6 \mathrm{~g} \mathrm{~m}^{-3}$ is found at $7800 \mathrm{~m}$ altitude $\left(T=-32{ }^{\circ} \mathrm{C}\right)$. Figure $2 \mathrm{c}$ and d confirm the prevailing southwesterly winds measured by the Falcon aircraft.

During the last part of the flight $(\sim 35 \mathrm{~min}$ after the satellite overpass) the Falcon flew through an overshooting convective cell near the cloud top at $11080 \mathrm{~m}$ altitude $(T=$ $-58^{\circ} \mathrm{C}$ ). The subsequent in situ observations of this cloud and their interpretation are the object of this paper.

\section{Remote sensing observations}

In this section we shall present combined remote sensing observations (satellite and airborne data) and cloud in situ measurements related to the description of the properties of a convective cell which overshoots the tropopause. The SEVIRI, CALIPSO and CloudSat observations taken at 12:32 UT are first presented. Then the airborne radar RASTA aboard the SAFIRE aircraft performed at 12:57 UT are discussed followed by the airborne measurements aboard the DLR Falcon (at 13:07 UT) including cloud in situ and remote data.

\subsection{Analysis of the observations from SEVIRI, CALIPSO and CloudSat}

Figure 3 displays false color composites of MET-9/SEVIRI observations (approx. $3.5 \times 5 \mathrm{~km}^{2}$ pixel size) on 26 May 2007 at 13:00 UT. The Falcon trajectory between 12:45 and 13:15 UT is superimposed on the SEVIRI image. The red segment indicates the in-cloud measurements $(13: 07: 30$ to 13:10:30 UT) related to the penetration into the convective cloud. The flight trajectory prior to the convective cloud penetration, and partially represented on Fig. 3, was carried out in an adjacent cirrus cloud located southwards to the convective cell. This flight pattern was designed to validate CALIPSO and CloudSat observations (Mioche et al., 2010a).

Despite a weak temporal coincidence with the airborne measurements, the CALIPSO and CloudSat observations (12:32 UT) prove to be useful in obtaining overview and evolution of the cloud situation. Figure 4 displays a composite representation (from top to bottom) of SEVIRI (taken at 12:30 UT, i.e. two frames before the image displayed on Fig. 3), WFC reflectance and IIR brightness temperature images and the vertical profiles from CALIOP (attenuated backscatter coefficient) and the equivalent reflectivity factor from CloudSat. These observations, are plotted along the CALIPSO track between 48.5 and $49.5^{\circ} \mathrm{N}$ of latitude (study area). The swath of WCF being $61 \mathrm{~km}$ wide, the SEVIRI image has been sized accordingly. The results show that $\sim 35$ min before the cloud in situ measurements, the CALIPSO/CloudSat satellites overpass the convective system located around $49^{\circ} \mathrm{N}$.

The SEVIRI, WFC and IIR images give qualitatively a rather coherent picture of the cloud field. The WFC image (Fig. 4b) depict a typical feature of a convective system (located between $48.85^{\circ}$ and $49.0^{\circ} \mathrm{N}$ ) with, at least, three individual cells characterized by high reflectance near the cloud top indicating very dense clouds. Low IIR brightness temperatures of $218-220 \mathrm{~K}$ at $12.05 \mu \mathrm{m}$ are found in these areas (Fig. 4c). Compared to the SEVIRI image at 13:00 UT (i.e. $28 \mathrm{~min}$ later or $7 \mathrm{~min}$ prior to the DLR Falcon in situ observations), the cloud system is observed roughly at the same location whereas the surrounding cirrus clouds are advected according to the main wind at these levels $\left(25 \mathrm{~ms}^{-1} / 200^{\circ}\right)$. CALIOP and CloudSat profiles exhibit very well the convective cell with high values of the attenuated backscatter coefficient $(\beta)$ with strong signal attenuation at lowermost levels over a distance of about $50 \mathrm{~km}$ along the satellite track. These anomalously high values of CALIOP integrated attenuated backscatter near the top of center layers have recently be analyzed in mesoscale convective systems (MCS, Platt et al., 2011). The top of the overshooting cell is detected at $10900 \mathrm{~m}$ whereas the altitude of the surrounding cirruscloud top is estimated at $10700 \mathrm{~m}$. It should be noted that the subsequent profile of the CALIOP depolarisation ratio (not shown here) does not reveal any indication of oriented pristine ice crystals and therefore cannot explain the high $\beta$ values observed in the overshooting cell and in the surrounding cirrus (between 49.0 and $49.13^{\circ} \mathrm{N}$ ). The CloudSat profile (Fig. $4 \mathrm{e})$, reveals a low reflectivity $(\sim 0 \mathrm{dBZ})$ near cloud top and a significant echo down to the surface due to precipitating particles. We shall strengthen these results with the airborne observations from the RASTA radar. 


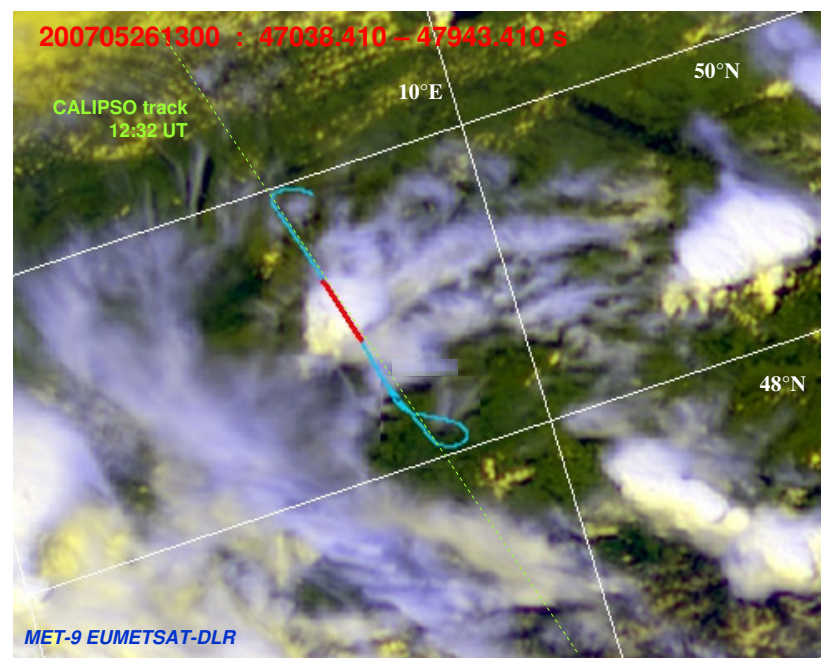

Fig. 3. False color composites of MET-9/SEVIRI observations from 26 May 2007 at 13:00 UT. The Falcon trajectory (between 12:45 and 13:15 UT) is superimposed (blue line). The flight segment in red color indicates the penetration in the convective cloud. The CALIPSO track (at 12:32 UT) is also displayed.

\subsection{Airborne equivalent reflectivity measurements from RASTA}

As mentioned above, the SAFIRE Falcon overpassed the cloud system following a flight trajectory co-located with the CALIPSO track. The observations were carried out at 12:57 UT, i.e. $\sim 25 \mathrm{~min}$ after the CALIPSO time and about 10 min prior to the DLR Falcon in situ measurements. Figure 5a displays the vertical profile of the RASTA equivalent reflectivity factor measured along the SAFIRE Falcon trajectory. Compared to the CloudSat profile on Fig. 4e the differences between the vertical cloud structures are likely due to the weak temporal coincidence with the satellite observations and subsequent combined time variations and advection of the cloud system. However, the overshooting cell is well described with rather large vertical gradients of the equivalent reflectivity factor near the cloud top detected at $11300 \mathrm{~m}$. Therefore, we may conclude that the convective cell overshoots by up to $600 \mathrm{~m}$ the tropopause level (estimated at $10700 \mathrm{~m}$ from the aircraft sounding, Fig. 2) whereas a significant increase of the high-reflectance horizontal area is observed from SEVIRI images between 12:30 and 13:00 UT (cf. Figs. 4a and 3, respectively). We shall describe now in detail the measurements performed with the DLR Falcon at $11080 \mathrm{~m}$, i.e. 200 to $300 \mathrm{~m}$ below the top of the overshooting cell.

\subsection{Aircraft measurements on the DLR Falcon}

Figure 6 (upper panel) represents the time-series $(1 \mathrm{~Hz})$ of cloud in situ parameters, namely: the concentration of ice particles with diameter larger than $3 \mu \mathrm{m}$ and $100 \mu \mathrm{m}$ (Conc

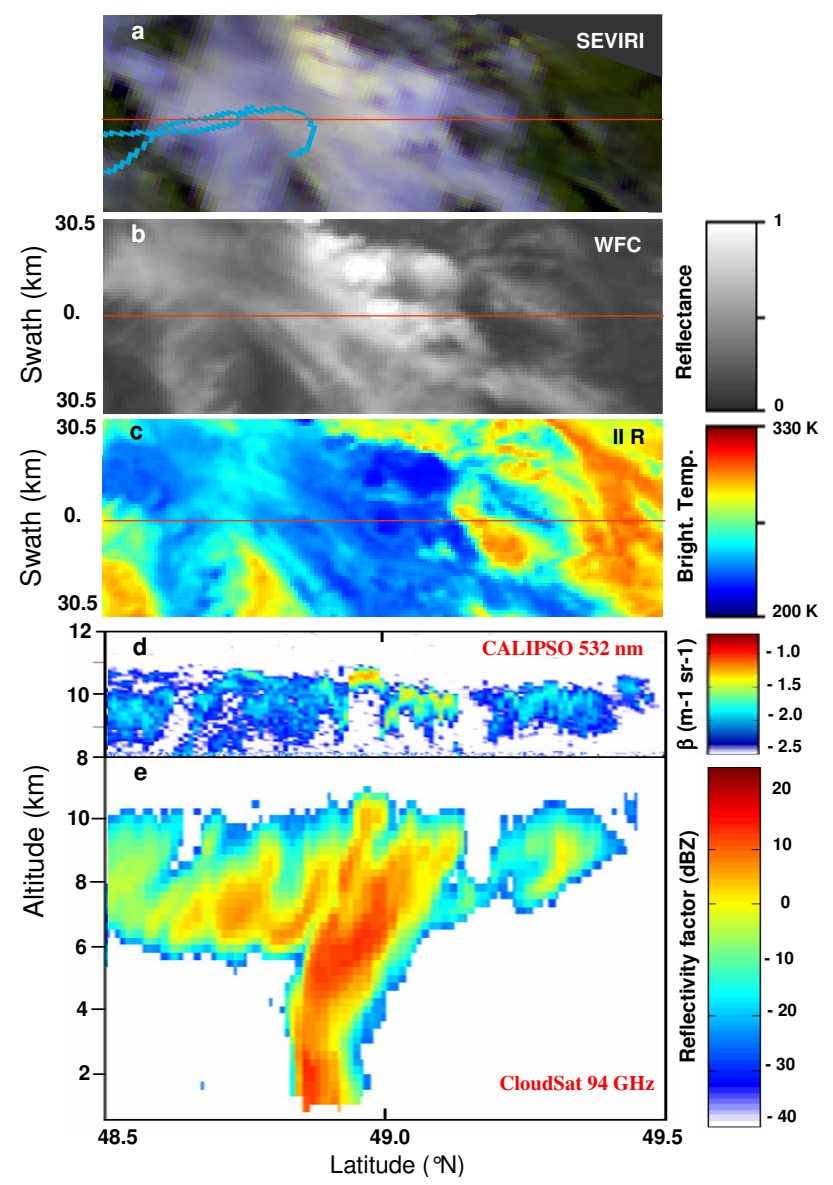

Fig. 4. Composite-latitude representations (between 48.5 and $49.5^{\circ} \mathrm{N}$, i.e. area study) of: (a) SEVIRI (color composite); (b) Wide Field Camera (WFC) images; (c) Imaging Infrared Radiometer (IIR); (d) Vertical profile of the attenuated backscatter coefficient from CALIOP and (e) vertical profile of the equivalent reflectivity factor from CloudSat. CALIPSO (WCF, IIR and CALIOP) and CloudSat observations were taken at 12:32 UT. The Falcon trajectory (from 12:15 to $12: 45$ ) is superimposed on the SEVIRI image (taken at 12:30 UT). The CALIPSO trace (red line) is reported on SEVIRI, WFC and IIR images.

and $C 100$, respectively), both inferred from FSSP-300 and CPI data, the extinction coefficient and the asymmetry parameter (Ext and $g$, respectively), derived from the Polar Nephelometer, the effective diameter (see definition in Gayet et al., 2004), the ice water content and the equivalent reflectivity factor (Deff, IWC and $Z$, respectively) calculated from FSSP-300 and CPI data. The results of two distinct cloud flight sequences are reported: firstly from 12:42-12:55 UT which relates cirrus observations (see horizontal trajectory on Fig. 3), and secondly from 13:03-13:13 UT with observations during the convective cell penetration (see red segment on Fig. 3). We note in passing that no cloud was experienced between 12:55 and 13:03 UT, the two sequences have been separated for simplicity on Fig. 6. A first overview of 

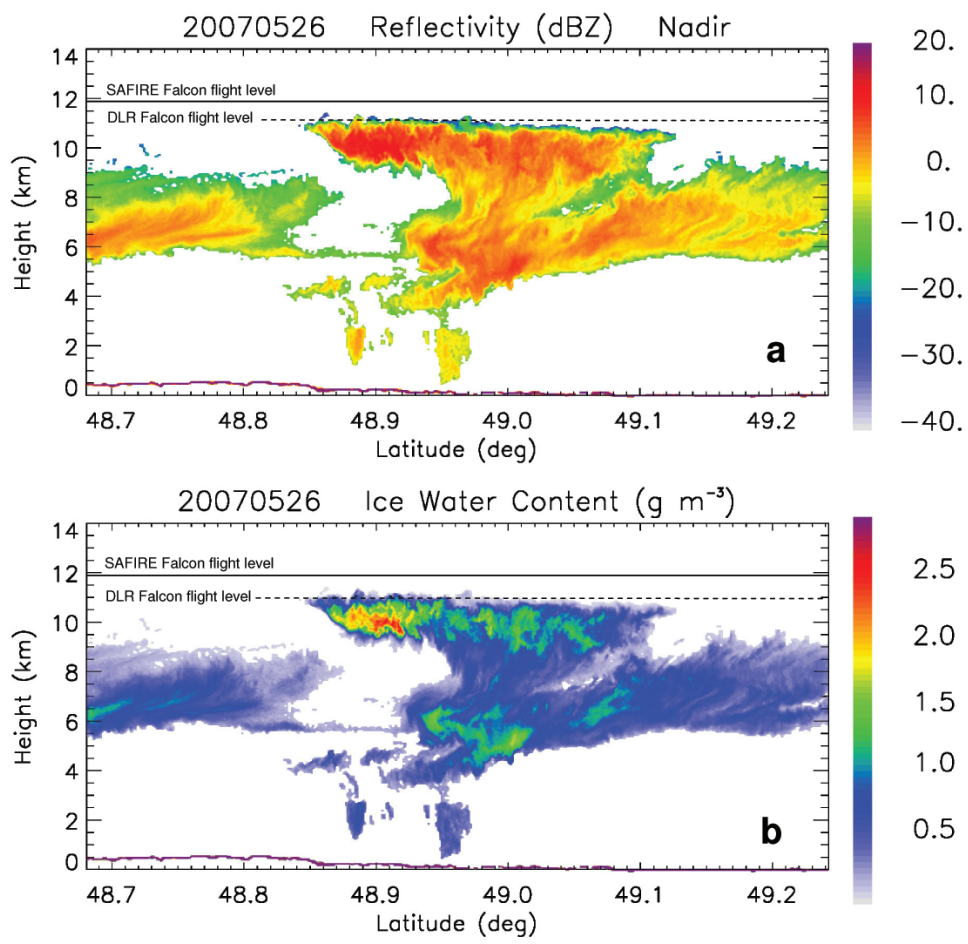

Fig. 5. Airborne RASTA radar observations along the SAFIRE aircraft trajectory at 12:57 UT. (a): Vertical profile of the equivalent reflectivity at $95 \mathrm{GHz}$ and (b): Vertical profile of the retrieved ice water content. The flight altitudes of the SAFIRE and DLR Falcon aircraft are indicated with full and dotted lines, respectively.

the results highlights significant differences in microphysical and optical properties between the convective cell and cirrus. Unusual high values of ice particles concentration, extinction and ice water content are experienced in the convective cell particularly when compared with the cirrus properties, i.e. $54 / 6 \mathrm{~cm}^{-3}, 19.8 / 3.1 \mathrm{~km}^{-1}, 0.44 / 0.05 \mathrm{~g} \mathrm{~m}^{-3}$ (mean values) contrasting with smaller effective diameters $(43 / 80 \mu \mathrm{m})$ and similar equivalent reflectivity factors $(\sim 0 \mathrm{dBZ})$. These measurements will be discussed with details in Sect. 4 below.

Figure 6 (middle panel) displays the vertical profile of the attenuated backscatter ratio (at $1064 \mathrm{~nm}$ ) from the WALES lidar along the flight trajectory. The altitude of the Falcon (also reported on Fig. 6: black curve) shows that during the first sequence the flight altitude increases from $8100 \mathrm{~m} /-33^{\circ} \mathrm{C}$ to $10800 \mathrm{~m} /-56^{\circ} \mathrm{C}$. The second sequence was performed at a constant level: $11080 \mathrm{~m} /-58^{\circ} \mathrm{C}$. The cirrus optical depth (in the visible) underneath the flight level has been evaluated to 3 from averaged in situ extinction profiles. Therefore the lidar signal can describe all the cirrus depth. To the contrary, the lidar returns are fully attenuated as soon as the aircraft penetrates the convective cell (see microphysical measurements on the upper panel from 13:07:30 to 13:10:30 UT). This nicely confirms the CALIOP observations reported above (see Fig. 4d) with high attenuated backscatter values (up to $0.67 \mathrm{~km}^{-1} \mathrm{sr}^{-1}$ ) and high depolarization ratio (up to 0.7 ).
These properties are expected especially for small ice crystals (Mishchenko and Sassen, 1998). In this way, the in situ observations of the high concentration of small ice particles are further evidenced by the observation of the high depolarisation ratio for this specific deep convection cloud. Furthermore the global survey of CALIOP linear depolarisation ratios by Sassen and Zhu (2009) shows that high depolarisation ratios are found predominantly at low latitudes, a region where deep convection is most frequent.

As for the cloud particles, they are definitively ice crystals since the temperature is $-58^{\circ} \mathrm{C}$, a value much below the temperature for which the supercooled liquid water droplets freeze by homogeneous nucleation $\left(-37^{\circ} \mathrm{C}\right)$. On the other hand, the asymmetry factor is smaller than 0.8 (see Fig. 6) indicating ice crystals occurrence as confirmed by CPI images (see Sect. 4.1). A careful examination of the measurements indicates that the aircraft was flying just above the convective cloud top from 13:10:30 UT (as soon as it leaves the cell) to 13:11:05 UT (end of attenuated lidar returns).

Figure 6 (bottom panel) represents the time-series of retrieved parameters from SEVIRI observations along the horizontal Falcon trajectory, namely: the effective radius, the optical depth and the brightness temperature (green curve) in the IR channel at $10.8 \mu \mathrm{m}$ with the air temperature measured by the Falcon (black curve). The inversion technique of the SEVIRI spectral data has been described by Bugliaro 


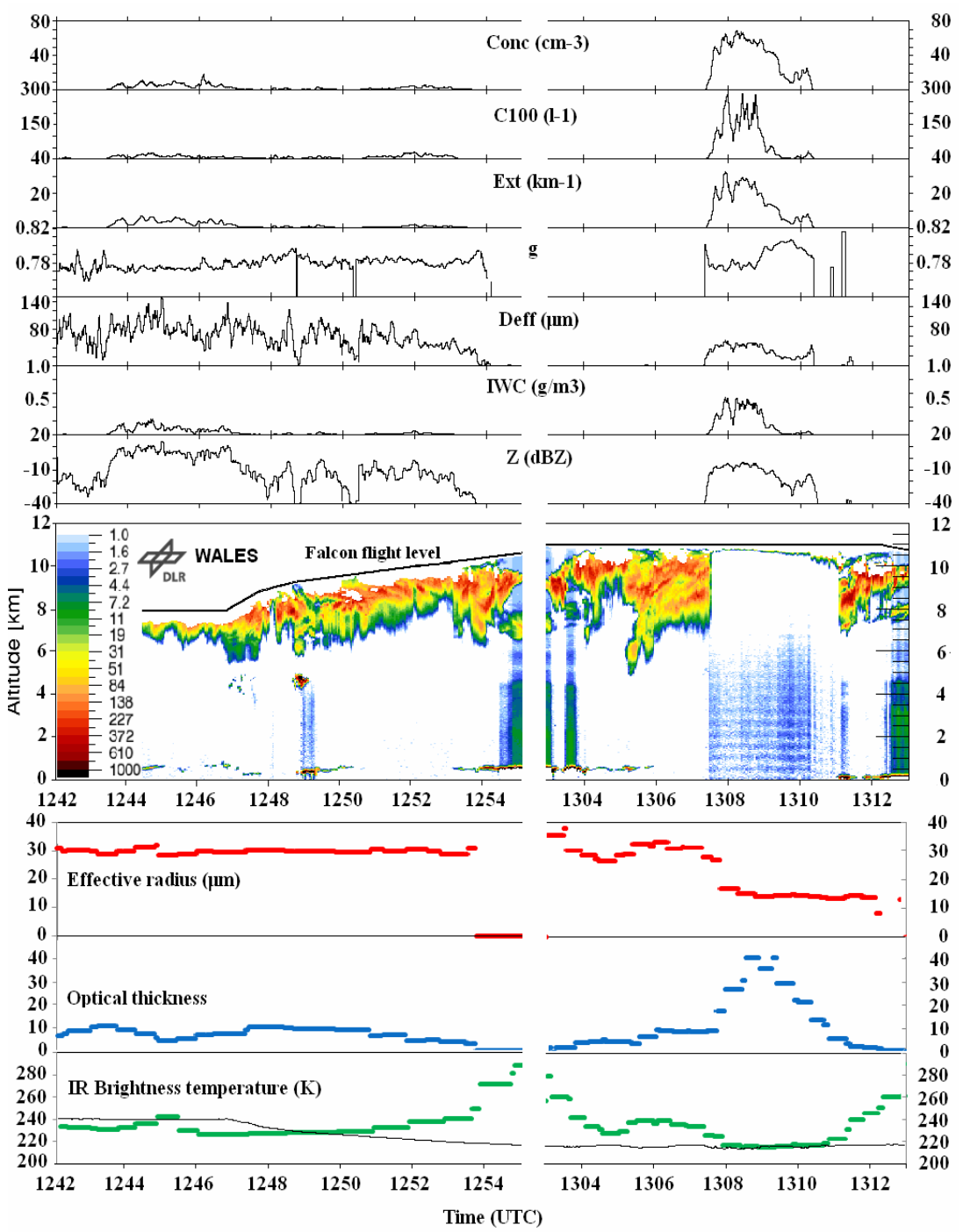

Fig. 6. 1st panel: Time-series of cloud in situ parameters: Conc and C100: Concentration of ice particles $(d>3 \mu \mathrm{m}$ and $d>100 \mu \mathrm{m}$, respectively); Ext: Extinction, $g$ : Asymmetry parameter; Deff: Effective diameter; IWC: Ice water content and Z: Reflectivity factor. 2nd panel: Attenuated backscatter ratio (at $1064 \mathrm{~nm}$ ) from WALES lidar. $3 \mathrm{rd}$ panel: Time-series of retrieved parameters from SEVIRI observations along the Falcon flight: Effective radius, Optical depth and Brightness temperature (green curve) in the IR channel (10.8 $\mu \mathrm{m})$ with the air temperature measured by the Falcon (black curve). The first sequence reports cirrus (12:42-12:55 UT). The sequence from 13:03 to $13: 13 \mathrm{UT}$ describes the overshooting convective cloud sampled near the top at $11080 \mathrm{~m} /-58^{\circ} \mathrm{C}$ level.

et al. (2011) for the retrieval of the cloud properties (top height, thermodynamic phase, optical thickness, effective radius, cloud water path, ...). For validation purposes, this technique can provide retrieved cloud products along aircraft research flights by navigating the flight trajectory within the satellite coordinates. Because the SEVIRI data are available every $15 \mathrm{~min}$, errors in collocation could be considered due to differences between SEVIRI and Falcon data acquisition times ( \pm 7.5 min maximum time lag). The SEVIRI retrieved parameters confirm the occurrence of small ice crystals in the convective cell compared to the cirrus (effective radius of $\sim 15 \mu \mathrm{m}$ versus $60 \mu \mathrm{m}$ ) with high optical thickness (40). The
IR brightness temperature fits remarkably well with the in situ temperature measurements near the top of the convective cell $\left(215 \mathrm{~K},-58^{\circ} \mathrm{C}\right)$. We note in passing that the temperature retrieved from IIR is greater $\left(-53^{\circ} \mathrm{C} / 220 \mathrm{~K}\right.$, see Fig. $\left.4 \mathrm{c}\right)$ maybe because the lower altitude of the cloud top $(10900 \mathrm{~m})$ detected by CALIOP 28 min earlier. 

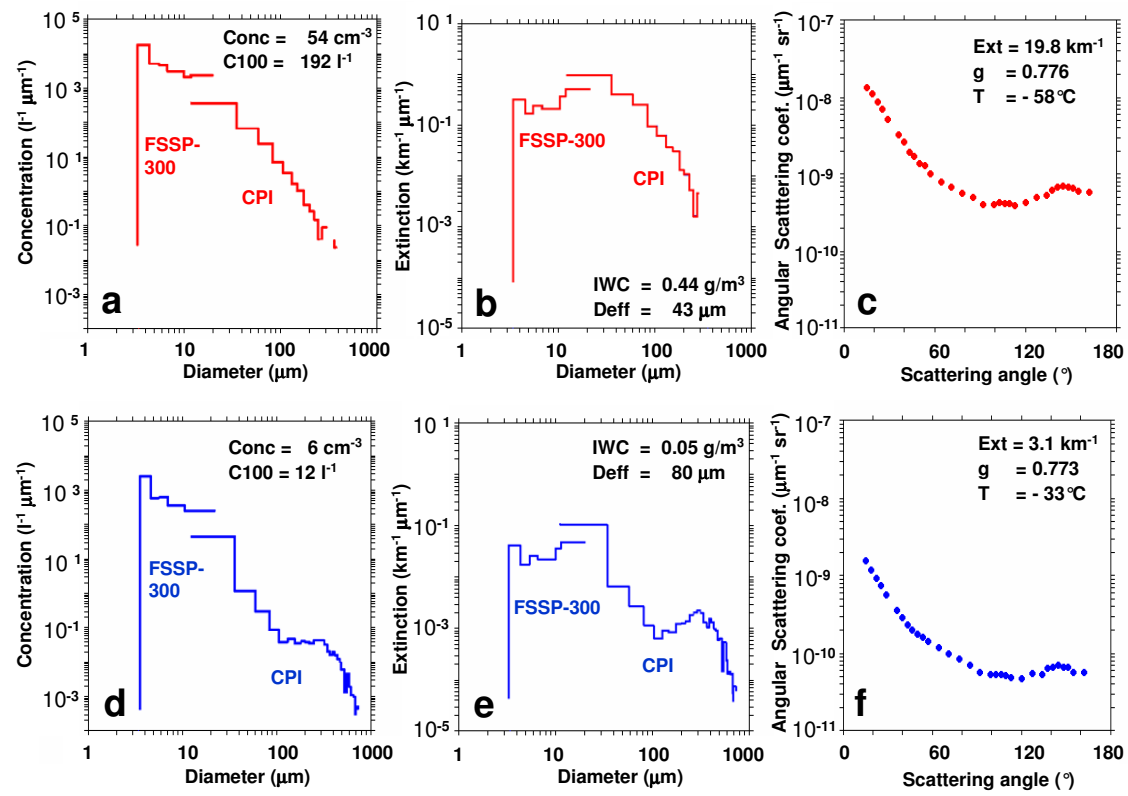

Fig. 7. Mean microphysical and optical properties of the overshooting cell (13:08:15-13:08:40 UT) and the cirrus (12:43:30-12:46:40 UT): (a) and (d) Particle size distributions; (b) and (e): Particle extinction distributions; and (c) and (f): Scattering phase functions, respectively. The mean values of the parameters over the indicated cloud sequences are reported. Conc: Ice partice concentration; $C 100$ : Concentration of particles with $d>100 \mu \mathrm{m}$; IWC: Ice water content; Deff: Effecive diameter; Ext: Extinction coefficient; $g$ : Asymmetry parameter; and $T$ : Temperature.

\section{Cloud in situ measurements and retrieved observations}

\subsection{On the microphysical and optical properties}

In the following we focus on the cloud in situ measurements performed near the top of the overshooting convective cell (from 13:07:50 to 13:09:10 UT, see Fig. 6). For comparison purposes the properties of the surrounding cirrus cloud (from 12:43:30 to 12:46:40 UT) will also be discussed. Coming back to Fig. 6, the results show that the aircraft penetration of the overshooting cell lasted $3 \min$ (13:07:30-13:10:30 UT) which corresponds to a horizontal distance of $36 \mathrm{~km}$. Unusual high values of the ice particle concentration, extinction, ice water content (up to $70 \mathrm{~cm}^{-3}, 30 \mathrm{~km}^{-1}$ and $0.5 \mathrm{~g} \mathrm{~m}^{-3}$, respectively) are experienced. The frequency of occurrence of IWC shows that IWCs larger than $0.3 \mathrm{~g} \mathrm{~m}^{-3}$ occurred $50 \%$ of the penetration time. From our knowledge these values were never observed in convective clouds at mid-latitude in Western Europe at such low temperature $\left(-58^{\circ} \mathrm{C}\right)$. IWC from 1.5 to $2.5 \mathrm{~g} \mathrm{~m}^{-3}$ were reported in anvils of intense midlatitude storms over the Great Plains of USA (Heymsfield and Palmer, 1986; Lawson et al., 1998). Likewise in Tropical convective turrets clouds, ice water content exceeding $2 \mathrm{~g} \mathrm{~m}^{-3}$ and extinction up to $60 \mathrm{~km}^{-1}$ have been measured (Lawson et al., 2010). High concentration of small ice crystals (up to $100 \mathrm{~cm}^{-3}$ ) have been measured near the top of Tropical cumulonimbus (Knollenberg et al., 1993). In sub- tropical and Tropical convection Heymsfield et al. (2005) and Heymsfield et al. (2006) reported high concentration of small ice crystals in the order $50 \mathrm{~cm}^{-3}$ and even in maritime Tropical convective updrafts (Heymsfield et al., 2009).

Figure 7 displays the mean microphysical and optical properties of the overshooting cell (13:08:15-13:08:40 UT) and the cirrus (12:43:30-12:46:40 UT) with the representations of: (a) and (d) the particle size distributions, (b) and (e) the extinction size distributions and (c) and (f) the scattering phase functions, respectively. The mean values of the parameters over the indicated cloud sequences are also reported. The results show that the rather narrow particle size distribution observed in the overshooting cell (Fig. 7a) carries about 10 times more ice particles (and subsequent bulk parameters) than the values of the cirrus cloud with a much broader size spectrum (Fig. 7d). The corresponding effective diameters are $43 \mu \mathrm{m}$ and $80 \mu \mathrm{m}$ and the maximum particle sizes are $\sim 300 \mu \mathrm{m}$ and $\sim 1 \mathrm{~mm}$, respectively. The extinction size distributions for the two clouds (Fig. $7 \mathrm{~b}$ and e) show rather acceptable qualitative agreements in the probe sizebins overlapping. It should be noted that in both cases most of the extinction is carried by particles with effective diameters between about 15 and $35 \mu \mathrm{m}$. We recall that this size range is the most affected by the inherent shortcomings on probes and data processing, which limit the accuracy of derived microphysical and optical parameters reported in this paper. 

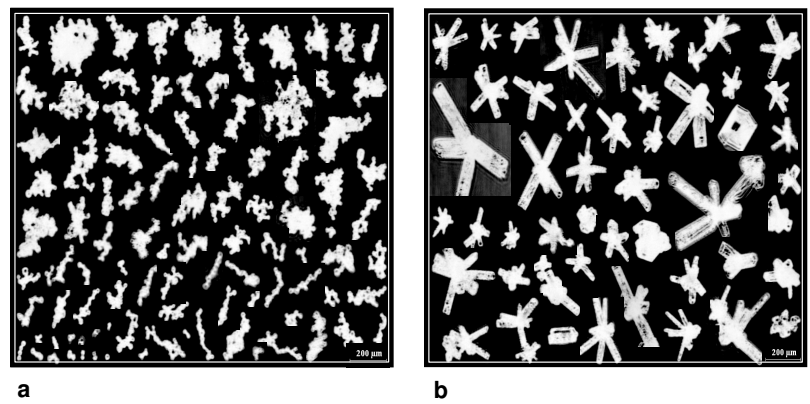

Fig. 8. Examples of ice crystal images measured by the CPI instrument. (a): Chain-like aggregates observed near the top of the overshooting cell $\left(11080 \mathrm{~m} /-58^{\circ} \mathrm{C}\right)$. (b): Bullet-Rosettes sampled near $-45^{\circ} \mathrm{C}$ in the cirrus.

Smooth and featureless phase functions (Fig. 7c and f) with similar asymmetry factors $(0.776$ and 0.773 , respectively) indicate fairly uniform optical properties. This confirms previous observations (Gayet et al., 2011) that particles with imperfect or complex shapes are prevalent in ice clouds. Indeed, examples of ice crystal images measured by the CPI instrument are displayed on Fig. 8. While BulletRosettes are observed in the cirrus near $-45^{\circ} \mathrm{C}$ (Fig. 8b), a common feature for in situ cirrus forming (see among others, Sassen et al., 2001), typical chain-like aggregates ice crystals are highlighted near the top of the overshooting convective cloud (Fig. 8a). Chains of ice crystals have already been observed at low temperatures (below $-43^{\circ} \mathrm{C}$ ) in anvils from continental deep convective clouds by Stith et al. (2002), Lawson et al. (2003) and Connolly et al. (2005). From the particle samples displayed on Fig. 8a the distinction between typical chains of particles and aggregates with heavy irregular shapes could be somewhat arbitrary. The largest particles are qualitatively recognized having mostly $3 \mathrm{D}$ irregular shapes resembling sometimes to "graupels" although they have no definite central crystal seed. A visual classification roughly gives a proportion of $70 \%$ of typical chains of ice crystals and ice particles exhibiting a faceted shape have been rarely observed. These properties are experienced all along the overshooting cloud penetration. The explanation for the occurrence of chain-like aggregate ice crystals will be discussed in Sect. 5 below.

\subsection{On the IWC-Z relationship and application to radar measurements}

The IWC-Z relationships are key issues for deriving the cloud ice water content from retrieved equivalent reflectivity factors obtained with remote sensing (airborne or spaceborne) observations. The cloud in situ measurement data set reported above can be used in order to assess these IWC-Z relationships. Figure 9 displays the results with both parameters calculated from the FSSP-300 and CPI instruments at

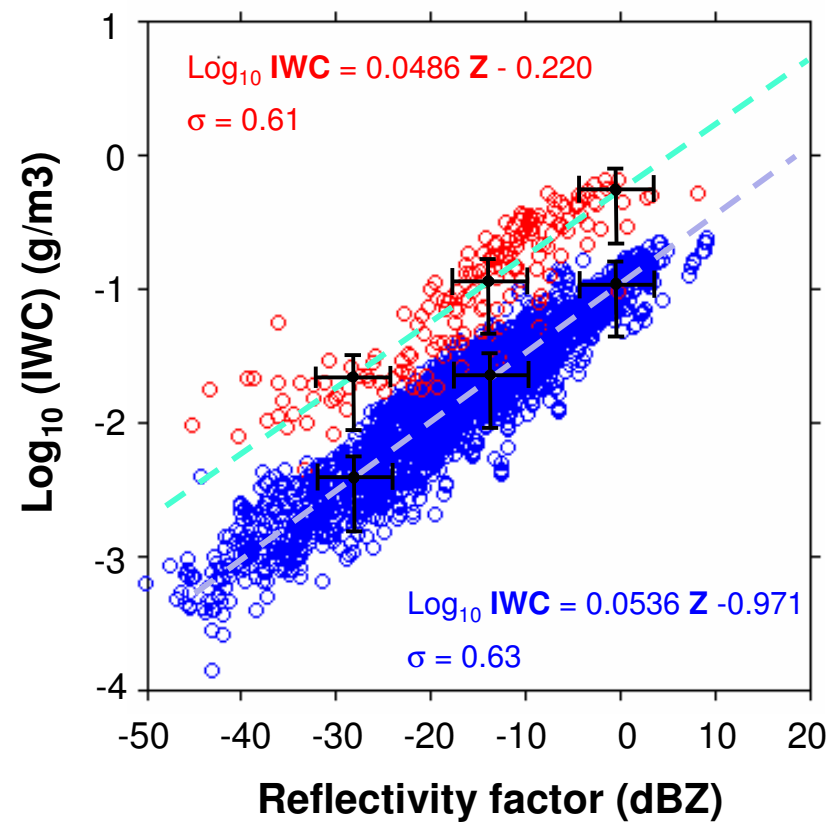

Fig. 9. IWC-Z relationships for the convective overshooting cloud and the cirrus observations (red and blue symbols, respectively). The slope parameters and correlation coefficients are reported. Horizontal and vertical bars represent the uncertainties on the equivalent radar reflectivity $( \pm 4 \mathrm{dBz})$ and on the ice water content $(100 \%)$ derivations, respectively.

$1 \mathrm{~Hz}$ frequency. Two distinct linear tendencies are clearly sorting out according to the considered cloud types with different power-law curves fitted through the data. It should be noted that the relationship for the cirrus is similar to the results from previous works related to cirrus cloud observations (see among others Protat et al., 2007 and Sayres et al., 2008). For a given equivalent reflectivity factor, IWCs are significantly larger for the overshooting cell than for the cirrus. Indeed, $Z$ and IWC being proportional to the 6th and 3rd moment of the size distribution respectively, the differences in the respective power-laws are explained by smaller particle sizes (see Fig. 7a and b) in the convective cloud.

It is interesting now to apply the above results to the available equivalent reflectivity measurements from the airborne RASTA radar (see Sect. 3.2). We recall that the highest cloud tops were detected near $11300 \mathrm{~m}$, meaning that the in situ DLR Falcon observations were performed 200 to $300 \mathrm{~m}$ below the cloud top. Nevertheless, the direct comparisons between radar and in situ data are hampered by the weak temporal coincidence $(\sim 10 \mathrm{~min})$ of the combined observations and the combined-accuracies of both aircraft altitude measurements $( \pm 100 \mathrm{~m})$ which are critical in this issue due to strong vertical gradients of the reflectivity near the cloud top (see Fig. 5a). Applying the IWC-relationship experienced in the convective cloud from in situ measurements (see Fig. 9), 
the RASTA equivalent reflectivity radar profiles could be scaled into ice water content assuming, of course, same prevalent microphysical properties over the cloud depth. The results are displayed on Fig. 5b and show that IWC up to $1 \mathrm{~g} \mathrm{~m}^{-3}$ may be observed within a layer depth of $\sim 300 \mathrm{~m}$ below the cloud top. IWCs up to $2 \mathrm{~g} \mathrm{~m}^{-3}$ (corresponding to radar reflectivities of about $15 \mathrm{dBZ}$ ) are retrieved over a distance of $2.5 \mathrm{~km}$ at the $10000 \mathrm{~m}$ level.

Extrapolating the relationship for stronger convective systems with similar ice particles, IWC up to $5 \mathrm{~g} \mathrm{~m}^{-3}$ could be experienced with reflectivity factor no larger than $20 \mathrm{dBZ}$. This means that for similar situations, indication of rather weak radar echo does not necessarily warn the occurrence of high ice water content carried by small ice crystals. This is maybe the reason why the DLR Falcon's pilots decided to safely fly into the storm having no significant or warningindicative signal returns from the onboard radar. These unusual observations could be important regarding engineering issues related to the failure of jet engines commonly used on commercial aircraft during flights through areas of high ice water content as reported by Lawson et al. (1998), Strapp et al. (1999) and Mason et al (2006). From the analysis of 46 jet engine power loss events, Mason et al. (2006) mentioned that no flight-radar echoes at the location and altitude of the event is part of common observations in transport aircraft. The events were recorded over continental areas with some of them over Western Europe.

Nevertheless we must keep in mind the large uncertainties of the relationships above (i.e. data dispersion on Fig. 9) mainly due to probe shortcomings and errors in deriving IWC and $Z$ associated to the hypothesis in crystal mass-size variations and ice density. Furthermore a just a few large particles can swamp the reflectivity calculations as exemplified by the reflectivity distribution on Fig. B1d (Appendix B) measured in the overshooting cell. The results show a poor statistical representation of particles larger than about $250 \mu \mathrm{m}$ due to the CPI sampling volume. This is confirmed by the careful examination of the CPI ice-crystal images (recorded in the convection cell penetration), which did not reveal particles larger than $300 \mu \mathrm{m}$. Considering a subsequent underestimation about $30 \%$ of the reflectivity expressed in $\mathrm{mm}^{6} \mathrm{~m}^{-3}$, this correspond to $50 \%$ on $\mathrm{dBZ}$, a value which is within the error bars of the measured reflectivity. The reflectivity factor derivation considers a $94 \mathrm{GHz}$ wavelength (CloudSat radar) for which the Mie effects become important for particles larger than $\sim 500 \mu \mathrm{m}$ (Boudala et al., 2006). Usually, the relationships describing the properties of deep convective systems are drawn up from C-band radars which are dedicated to precipitation observations (see for instance Bringi et al., 1984).

\section{Interpretation of the observations of the overshooting cell}

The overshooting convective cloud sampled near the top at $11080 \mathrm{~m} /-58^{\circ} \mathrm{C}$ level is coherently described by combined in situ and remote sensing observations. These observations highlight very high concentration of small ice crystals with mostly chain-like aggregate shape measured all along the cloud penetration. As mentioned above chains of ice crystals have already been observed at low temperatures (below $-43^{\circ} \mathrm{C}$ ) in continental anvils. Connolly et al. (2005) reported that chain crystals were a very small fraction of the total population from measurements performed outside updraft regions (due to safety constraints). In our case the Falcon experienced the core of the cloud (see Fig. 3) during the overshooting phase of the convective system, explaining a much higher proportion of chains of ice crystals (see Fig. 8a). Our measurements confirm that chains of ice crystals are found in a continental deep convective system, which has presumably high concentration of aerosols. Although no direct observations of cloud electrical activity are available, these conditions are likely favourable for lightning occurrence. This feature is confirmed from the satellite climatology results by Sherwood et al. (2006) who found that lightning counts appear related to the amount of small ice (effective diameter $<30 \mu \mathrm{m}$ ) that appears at (continental) cloud top. Indeed, following the detailed discussion by Connolly et al. (2005) the ice particle aggregation processes are caused by intense electric fields. These researchers conclusively compared chains of ice crystals observed in cloud with previous laboratory experiments (see for instance Saunders and Wahab, 1975). Our measured ice number concentrations being high, this fulfils the requirement of Wahab (1974) for electrically enhanced aggregation $\left(>2 \mathrm{~cm}^{-3}\right)$. No laboratory observations being available at temperature lower than $-20^{\circ} \mathrm{C}$, the question whether the aggregation process is efficient at low temperature remains unanswered (Connolly et al., 2006).

The careful examination of the ice crystal images from the CPI clearly shows chains of particles of up to several tens of individual particles long (see typical examples on Fig. 10). The individual particles can easily be recognized to be frozen droplets, which often remain with a quasi-spherical shape and a diameter of 15-20 $\mu \mathrm{m}$. These observations may be explained by vigorous updrafts which lift supercooled droplets. Once they reach the $-37^{\circ} \mathrm{C}$ level $(8300 \mathrm{~m}$ in our case) the extremely rapid freezing of these droplets by homogeneous nucleation leads to very high concentration of small ice particles at upper levels. The aggregation process then takes place in presence of intense electric field. The observation of high ice water contents (up to $0.5 \mathrm{~g} \mathrm{~m}^{-3}$ ) near the cloud top compared to the maximum value of the theoretical adiabatic liquid water content at $8300 \mathrm{~m}\left(\sim 3.6 \mathrm{~g} \mathrm{~m}^{-3}\right)$ may be an indication of the entrainment of dry environmental air near the cloud top. At lower altitudes, the retrieved IWCs (up to $2 \mathrm{~g} \mathrm{~m}^{-3}$ ) from RASTA radar measurements are 
closer to the adiabatic value. This feature does not seem to be confirmed by measurements of the relative humidity (over ice) performed by the CR2 instrument (RHi) aboard the Falcon. Figure 11 displays the time-series of RHi with the vertical airspeed component, ice water content, effective diameter and asymmetry parameter. The results show that RHi remains close to $100 \%$ (with uncertainties of $\pm 11 \%$ ) over about $30-40 \%$ of the cloud penetration. Another observation which is important to underscore is the fact that extremely rare ice particles exhibit a faceted shape indicating that the growth regime via vapour deposition was definitely not efficient during the updraught lift. Therefore high concentrations of small ice particles typically produced by homogeneous nucleation are sufficient to deplete the water vapour (as confirmed with RHi measurements) and suppress further nucleation, even in very strong updrafts as discussed by Heymsfield et al. (2005). The vertical wind component on Fig. 11 rather shows moderate updrafts (up to $2 \mathrm{~m} \mathrm{~s}^{-1}$ ) with horizontal wind shear of $\pm 2 \mathrm{~m} \mathrm{~s}^{-1}$ likely because the observations address the cloud top properties. This may not preclude the possibility that much stronger updraughts occurred at lower levels which generated electric field high enough for enhancing ice particle aggregation process.

Figure 12a and b display the effective diameter and the asymmetry parameter as a function of RHi. The decrease of the effective diameter with decreasing RHi $(<100 \%$, Fig. 12a) is obviously an indication that the particles are sublimating. Conversely, the asymmetry parameter increases with RHi because the optical properties are controlled by the smallest particles, which have probably smoothed irregular shape compared to the largest chain ice crystals (see Fig. 10). These features occur preferentially outside the denser part of the cloud (i.e. IWC $<\sim 0.3 \mathrm{~g} \mathrm{~m}^{-3}$, see Fig. 11).

Despite large uncertainties on quantitative values of microphysical and optical parameters (ice particle concentration, extinction coefficient, ice water content), the combined in situ measurements and remote observations lead to a coherent description of the properties of the overshooting convective cloud. The strong attenuation of the WALES lidar returns even in the first lowermost cloud layers undoubtedly confirms a very dense cloud with high concentration of small ice particles and high extinction. A similar feature is observed from CALIOP data and the SEVIRI retrieved parameters confirm the occurrence of small ice crystals near the top the convective cell. These numerous small ice crystals may carry significant ice water content with conversely a low equivalent reflectivity factor. These observations address scientific issues related to the microphysical properties and structure of deep convective clouds and confirm that particles smaller than $50 \mu \mathrm{m}$ may control the radiative properties in convective-related clouds.

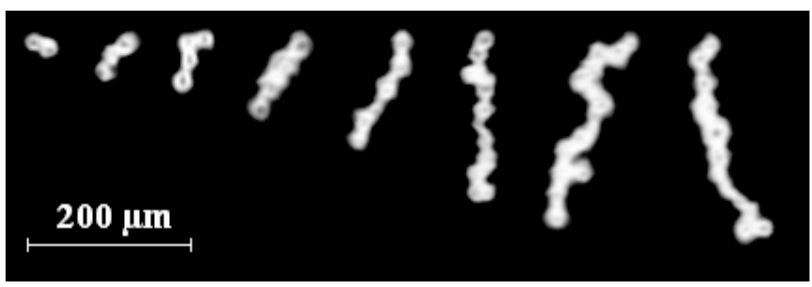

Fig. 10. Typical examples of chain-like aggregates ice crystals from 2 up to 15 individual frozen droplets.

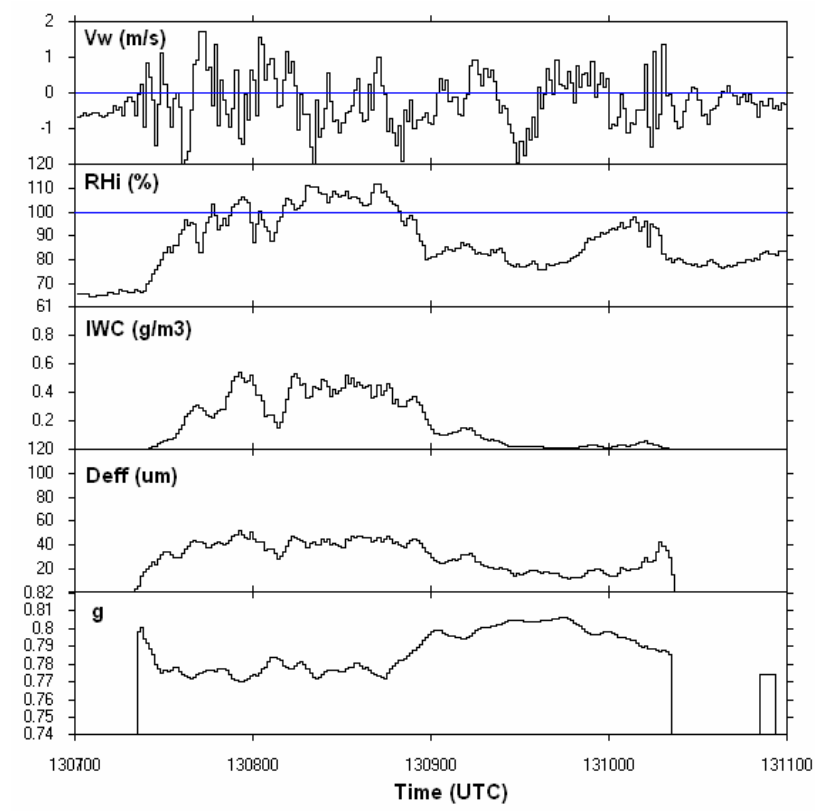

Fig. 11. Time-series of parameters measured in the overshooting cell (13:07-13:10 UT): $V w$ : wind component, RHi: Relative humidity over ice, IWC: ice water content, Deff: effective diameter and $g$ : asymmetry parameter.

\section{Conclusions}

In this paper we described combined in situ and remote sensing observations for the characterization of the microphysical and optical properties near the top $\left(11080 \mathrm{~m} /-58^{\circ} \mathrm{C}\right)$ of an overshooting convective cell in mid-latitude continental area over Europe. Quasi-simultaneous spaceborne observations from SEVIRI, CALIPSO and CloudSat combined with airborne RASTA radar reflectivity depict very well the convective cells which overshoot by up to $600 \mathrm{~m}$ the tropopause level estimated at $10.7 \mathrm{~km}$, i.e. the altitude of the surrounding cirrus cloud top.

Unusual high values of the ice particle concentration, extinction, ice water content (up to $70 \mathrm{~cm}^{-3}, 30 \mathrm{~km}^{-1}$ and $0.5 \mathrm{~g} \mathrm{~m}^{-3}$, respectively) are experienced. Ice water contents larger than $0.3 \mathrm{~g} \mathrm{~m}^{-3}$ occurred $50 \%$ of the penetration length (i.e. over $36 \mathrm{~km}$ long). From our knowledge these values 


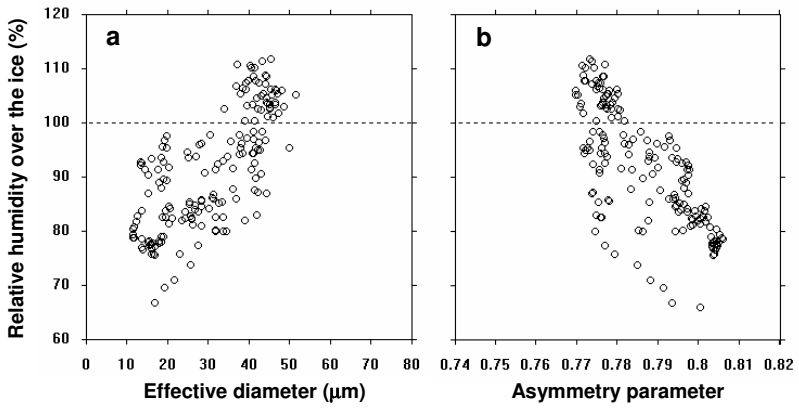

Fig. 12. (a) Effective diameter and (b) asymmetry parameter versus the relative humidity over the ice. The data concerns the overshooting cell.

were never observed in convective clouds at mid-latitude in Western Europe at such low temperature $\left(-58^{\circ} \mathrm{C}\right)$. These values, which characterize a very dense cloud, are confirmed by a strong attenuation of the WALES lidar returns, even in the first lowermost cloud layers. A similar feature is observed from the CALIOP data. The mean effective diameter is of $43 \mu \mathrm{m}$ and the maximum particle size is $\sim 300 \mu \mathrm{m}$. The SEVIRI retrieved parameters confirm the occurrence of small ice crystals at the top of the convective cell. Smooth and featureless phase functions with asymmetry factors of 0.776 indicate fairly uniform optical properties. This confirms previous observations that particles with imperfect or complex shapes are prevalent in ice clouds.

Two distinct linear tendencies of the IWC-Z relationships (ice water content - equivalent reflectivity factor) characterize the overshooting cell and the surrounding cirrus clouds. For a given equivalent reflectivity factor, IWCs are significantly larger for the overshooting cell than for the cirrus. The differences in the respective power-laws are explained by smaller particle sizes in the convective cloud. Assuming same prevalent microphysical properties over the cloud depth, RASTA reflectivity profiles scaled into ice water content show that retrieved IWC up to $1 \mathrm{~g} \mathrm{~m}^{-3}$ may be observed near cloud top.

Extrapolating the relationship for stronger convective systems with similar ice particles, IWC up to $5 \mathrm{~g} \mathrm{~m}^{-3}$ could be experienced with reflectivity factor no larger than $20 \mathrm{dBZ}$. This means that for similar situations, indication of rather weak radar echo does not necessarily warn the occurrence of high ice water content carried by small ice crystals. These observations could be important regarding engineering issues related to the failure of jet engines commonly used on commercial aircraft during flights through areas of high ice water content.

The other interesting observation concerns the shapes of the ice crystals, which are dominated by chain-like aggregate ice particle measured all along the cloud penetration. The ice crystal images from the CPI clearly show chains of particles of up to several tens of individual particles long. The individual particles are recognized to be frozen droplets which still remain with a quasi-spherical shape and a diameter of 15$20 \mu \mathrm{m}$. Our results confirm previous observations that the chains of ice crystals are found in continental deep convective systems which are known generally to be very electrically active. By comparing chains of ice crystals observed in cloud with previous laboratory experiments, Connolly et al. (2005) hypothesized that the ice particle aggregation processes are caused by intense electric fields.

The observations above suggest that the supercooled droplets lifted in the vigorous updrafts are frozen extremely rapidly by homogeneous nucleation near the $-37^{\circ} \mathrm{C}$ level, producing therefore high concentrations of very small ice particles. The aggregation process then takes place in presence of intense electric field. The observed ice water contents lower than the adiabatic values $\left(0.5 \mathrm{~g} \mathrm{~m}^{-3}\right.$ versus $\left.3.6 \mathrm{~g} \mathrm{~m}^{-3}\right)$ near the cloud top may be an indication of the entrainment of dry environmental air near. This feature does not seem to be confirmed by measurements of the relative humidity (over ice) which remains close to $100 \%$ over about $30-40 \%$ of the cloud penetration. Because ice particles exhibiting faceted shapes were rarely observed, this means that the growth regime via vapor deposition was definitely not efficient during the updraft lift. Therefore high concentrations of small ice particles typically produced by homogeneous nucleation are sufficient to deplete the water vapor (as confirmed by the RHi measurements) and suppress further nucleation, even in very strong updrafts.

Although large uncertainties about quantitative values of microphysical and optical parameters (ice particle concentration, extinction coefficient, ice water content), the combined in situ measurements and remote observations coherently describe the properties of the overshooting convective cloud. These observations address scientific issues related to the microphysical properties and structure of deep convective clouds and confirm that particles smaller than $50 \mu \mathrm{m}$ may control the radiative properties in convective-related clouds.

\section{Appendix A}

\section{Derivation of the ice extinction coefficient and ice water content}

In the present study the contributions of both the FSSP300 and the CPI measurements have been considered for the derivation of the extinction coefficient and the ice water content. The size calibration of the FSSP-300 used during previous works in cirrus and contrails with the DLR Falcon aircraft was described with detail by Gayet et al. (2002). We recall that the size calibration for aspherical particles consider the size-bin proposed by Borrmann et al. (2000) (i.e. T-matrix method). Differences in the size response between the calibrations for aspherical and spherical ice particles are 

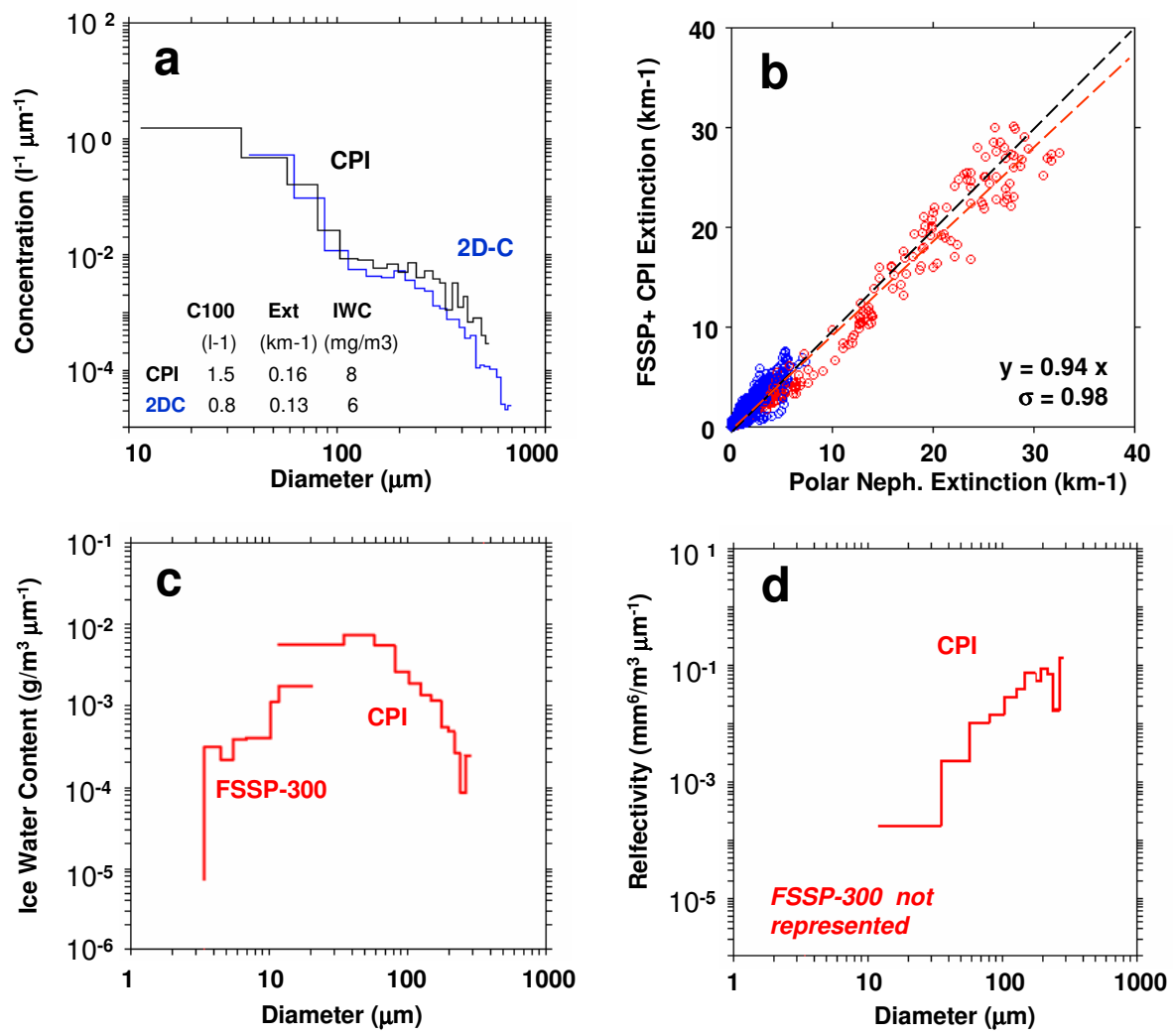

Fig. B1. (a): Composite representation of the size distributions measured simultaneously by the CPI and the 2-D-C probes (CIRCLE-2 16 May flight, 8:57:00-9:01:30 UT); (b): Comparison between extinction coefficients from Polar Nephelometer probe and combined FSSP-300 and CPI instruments. The red and blue dots relate the overshooting cell and the cirrus measurements, respectively. The slope parameters and correlation coefficients are reported; (c): Ice water content size distributions (overshooting cell) and (d): Reflectivity factor size distribution (overshooting cell).

little for sizes smaller than $4 \mu \mathrm{m}$ but then significantly increase with size. Shcherbakov et al. (2005) refined the upper size limit of last FSSP-300 channel $(21.8 \mu \mathrm{m})$ in order to obtain a good agreement with the first channel of the 2-D-C probe in terms of particle concentration, extinction and ice water content. Particles larger than $3 \mu \mathrm{m}$ diameter have been assumed to be ice crystals with an extinction efficiency of 2 (large particle assumption) and a density of $0.9 \mathrm{~g} \mathrm{~cm}^{-3}$.

As for the CPI, the IWC derivation involves the particle mass $(M) . M$ is calculated from the mass-size relationship which depends on the particle shape:

$M=\alpha D^{\beta}$

where $D$ is particle length, and $\alpha$ and $\beta$ are constants determined by linear regression. The values for small columns of $\alpha=0.206$ and $\beta=2.91$ (see Mitchell et al., 1990) have been considered as the best compromise with regards to the few available relationships for small ice crystals and our observations of chain-like aggregate ice crystals with dimensions ranging from 30 to $200 \mu \mathrm{m}$. This parameterisation gives the best (or the least worst) agreement in extinction comparisons (see Fig. B1b) and in the spectra behaviours of extinction (see Fig. 7b) and mass (see Fig. B1c) at the overlap between the FSSP-300 and the CPI.

\section{Appendix B}

\section{Validation of the CPI data}

In this work, since the PMS 2-D-C measurements are not reliable (see Sect. 2.2), the CPI data (with those from the PMS FSSP-300) are used to derive the particle size distributions and the microphysical parameters. The CPI calibration technique has already been thoroughly described in a previous paper (Gayet et al., 2009). We recall this technique aimed to reduce uncertainties on size distributions particularly for particles smaller than about $100 \mu \mathrm{m}$ from optical bench measurements which use calibrated glass beads and ice analogs (Connolly et al., 2007). As reported in Gayet et al. (2009), the calibration results were conclusively validated by comparing the CPI size distributions to available 2-D-C data as exemplified on Fig. B1a. We note in passing that Lawson et al. (2006b) scaled the CPI particle size distribution (PSD) 
with the 2-D-C PSD in the 200-300 $\mu \mathrm{m}$ size range where the 2-D-C PSD measurements are considered to be most reliable. A rather good agreement is found between the size distributions (with mostly Bullet-Rosette ice crystal shape in this case) and confirms previous comparison results in cirrus clouds (see Fig. 4 in Gayet et al., 2011). Mean values of the concentration of particles with $D>100 \mu \mathrm{m}$, extinction coefficient and ice water content from the CPI and PMS 2-D-C data are reported in Fig. B1a. The discrepancies are within the large uncertainties expected for the PMS instruments . The possible maximum error of $100 \%$ in mass mentioned in Gayet et al. (2002) refers to previous estimates for cirrus cloud FSSP-300/2-D-C measurements. Indeed, in the present cloud situation the maximum error on the mass could be much larger.

The coherence of the measurements could be verified from cross-correlations performed between extinction measurements obtained from two different techniques, i.e. Polar Nephelometer and combined FSSP-300 and CPI data. Fig. B1b reports cloud data obtained in the cirrus and the overshooting cell discussed in this paper (blue and red symbols, respectively). The results emphasize that the two measurements fit very well (slope parameter and correlation coefficient of 0.94 and 0.98 , respectively), even for very high extinction coefficients (up to $30 \mathrm{~km}^{-1}$ ) and for different size distributions.

\section{Appendix C}

\section{Reliability of the cloud measurements}

As introduced in the Sect. 2.2, most of the in situ microphysical observations collected with standard instruments (FSSP300, 2-D-C, CPI) could be contaminated by the shattering of larger ice crystals on the probe tips, resulting in artificially high concentrations of small ice crystals. There are still large uncertainties regarding the magnitude of the contribution of these small ice crystals to the bulk microphysical and radiative properties. Korolev and Isaac (2005), Lawson et al. (2006a) and Protat et al. (2010) suggested that small ice crystal do contribute significantly to these bulk microphysical properties whereas Jensen et al. (2009) showed that the small crystals contributed very little to ice water content and extinction in thick tropical cirrus. In relatively extreme situations, Heymsfield (2007) shows that shattering effects could add about $15 \%$ to the IWC from the FSSP, while the problem is even greater for extinction and number concentration. McFarquhar et al. (2007) confirm that shrouded inlets may cause particle shattering with a subsequent enhancement of the total concentration of ice crystals, especially at $D<50 \mu \mathrm{m}$. For particle diameters larger than about $100 \mu \mathrm{m}$, the number of shattered particles increases with the concentration of large particles.
It is conceivable that the effects of shattering depend on the design of the probe inlet as exemplified by Isaac et al. (2006) and Korolev et al. (2011) from laboratory high speed camera. The extinction coefficients are inferred from the FSSP$300+$ CPI and from the Polar Nephelometer probes, which all have very different inlet designs (for instance, inlet diameters of 40,23 , and $10 \mathrm{~mm}$, respectively). The hypothesis that the shattering of large ice crystals affects the FSSP-300+CPI and PN measurements in the same way, or with a same efficiency, appears unlikely. This is supported by the consistency of comparison results between extinctions calculated from two different techniques (FSSP-300 + CPI and PN) as displayed in Appendix B (see Fig. B1b) for the data obtained in the convective cell. This would appear unlikely if artefacts dominate the measurements in this case.

Referring now to recent works, Korolev et al. (2011) conclusively demonstrate the effects of ice shatteringcontamination on particle size distribution measurements from modified and no-modified probes. Large ice particles were found to produce a higher level of contamination, whereas when maximum particle sizes were $<500 \mu \mathrm{m}$, the effect was significantly reduced. Because the largest ice particle sizes measured being about $300 \mu \mathrm{m}$, it is likely that the standard FSSP measurements are not significantly affected by the ice shattering contamination during the sampling of the convective cloud.

New generation of cloud instruments (i.e. CDP, CIP, 2-D$\mathrm{S}, \ldots$ ) with specially designed tips and electronics can now provide much more accurate measurements by reducing significantly shattering of ice crystals and by making objective corrections possible (Field et al., 2006; Korolev et al., 2011; Lawson, 2011).

Acknowledgements. This work was funded by the Centre National d'Etudes Spatiales (CNES) and by a grant from the CNRS/INSU. The contribution of DLR as well as large part of Falcon flight hours was funded in the framework of the DLR PAZI-2 project. We thank U. Schumann and H. Mannstein for helpful discussions. We thank the members of DLR (Deutsches Zentrum für Luftund Raumfahrt) who organized the experiment management and aircraft operations. The Falcon's pilots M. Großrubatscher and S. Gemsa are acknowledged for fruitful comments on the flight. We acknowledge J. Pelon (LATMOS), A. Schwarzenboeck and J.-F. Fournol (LaMP), B. Weinzierl and H. Rüba (DLR) for their active participation to the CIRCLE-2 experiment. We acknowledge NASA Langley Research Atmospheric Science Data Center, as well as ICARE Center in Lille for the CALIPSO data. The authors are grateful to G. Isaac and the anonymous reviewer for important comments that strengthened the manuscript.

Edited by: J. Quaas 


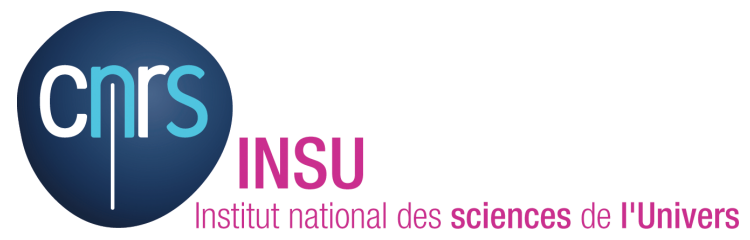

The publication of this article is financed by CNRS-INSU.

\section{References}

Abraham, J., Strapp, J. W., Fogarty, C., and Wolde, M.: Extratropical transition of Hurricane Michael, Bull. Amer. Met. Soc., 85, 1323-1339, 2004.

Bögel, W. and Baumann, R.: Test and calibration of the DLR Falcon wind measuring system by maneuvers, J. Atmos. Oceanic Technol., 8, 5-18, 1991.

Boudala, F. S., Isaac, G. A., and Hudak, D.: Ice water content and precipitation rate as a function of equivalent radar reflectivity and temperature based on in situ observations, J. Geophys. Res., 111, D11202, doi:10.1029/2005JD006499, 2006.

Bouniol, D., Protat, A., Plana-Fattori, A., Giraud, M., Vinson, J.P., and Grand, N.: Comparison of airborne and spaceborne 95$\mathrm{GHz}$ radar reflectivity and evidence of multiple scattering effects in spaceborne measurements, J. Atmos. Oceanic Technol., 25, 1983-1995, 2008.

Borrmann, S., Luo, B., and Mishchenko, M.: Application of the T-matrix method to the measurement of aspherical (ellipsoidal) particles with forward scattering optical particle counters, J. Aerosol Sci., 31, 789-799, 2000.

Bringi, V., Seliga, T., and Cooper, W.: Analysis of aircraft hydrometeor spectra and differential reflectivity (ZDR) radar measurements during the Cooperative Convective Precipitation Experiment, Radio Sci., 19, 157-167, 1984.

Bugliaro, L., Zinner, T., Keil, C., Mayer, B., Hollmann, R., Reuter, M., and Thomas, W.: Validation of cloud property retrievals with simulated satellite radiances: a case study for SEVIRI, Atmos. Chem. Phys., 11, 5603-5624, doi:10.5194/acp-11-5603-2011, 2011.

Busen, R. and Buck, A. L.: A high-performance hygrometer for aircraft use: Description, installation, and flight data, J. Atmos. Oceanic Technol., 12, 73-84, doi:10.1175/15200426(1995)012<0073:AHPHFA>2.0.CO;2, 1995.

Connolly, P. J., Saunders, C. P. R., Gallagher, M. W., Bower, K. N., Flynn, M. J., Choularton, T. W., Whiteway, J., and Lawson, R. P.: Aircraft observations of the influence of electric fields on the aggregation of ice crystals, Q. J. R. Meteorol. Soc., 131, 16951712, 2005.

Connolly, P. J., Flynn, M. J., Ulanowski, Z., Choularton, T. W., Gallagher, M. W., and Bower, K. N.: Calibration of the cloud particle imager probes using calibration beads and ice crystal analogues: The depth of field, J. Atmos. Oceanic Technol., 24, 1860-1879, 2007.

Eichler, H., Ehrlich, E., Wendisch, M., Mioche, G., Gayet, J.F., Wirth, M., Emde, C., and Minikin, A.: Influence of ice crystal shape on retrieval of cirrus optical thickness and effective radius: A case study, J. Geophys. Res., 114, D19203, doi:10.1029/2009JD012215, 2009.
Davis, S. M., Avallone, L. M., Kahn, B. H., Meyer, K. G., and Baumgärdner, D.: Comparison of airborne in situ measurements and Moderate Resolution Imaging Spectroradiometer(MODIS) retrievals of cirrus cloud optical and microphysical properties during the Midlatitude Cirrus Experiment (MidCiX), J. Geophys. Res., 114, D02203, doi:10.1029/2008JD010284, 2009.

Field, P. R., Heymsfield A. J., and Bansemer, A.: Shattering and interarrival times measured by optical array probes in ice clouds, J. Atmos. Oceanic Technol., 23, 1357-1371, doi:10.1175/JTECH1922.1, 2006.

Fridlind, A. M., Ackerman, A. S., Jensen, E. J., Heymsfield, A. J., Poellot, M. R., Stevens, D. E., Wang, D., Miloshevich, L. M., Baumgärdner, D., Lawson, R. P., Wilson, J. C., Flagan, R. C., Seinfeld, J. H., Jonsson, H. H., VanReken, T. M., Varutbangkul, V., and Rissman, T. A.: Evidence for the predominance of midtropospheric aerosols as subtropical anvil nuclei, Science, 304, 718-722, doi:10.1126/science.1094947, 2004.

Frey, W., Borrmann, S., Kunkel, D., Weigel, R., de Reus, M., Schlager, H., Roiger, A., Voigt, C., Hoor, P., Curtius, J., Krämer, M., Schiller, C., Volk, C. M., Homan, C. D., Fierli, F., Di Donfrancesco, G., Ulanovsky, A., Ravegnani, F., Sitnikov, N. M., Viciani, S., D’Amato, F., Shur, G. N., Belyaev, G. V., Law, K. S., and Cairo, F.: In situ measurements of tropical cloud properties in the West African Monsoon: upper tropospheric ice clouds, Mesoscale Convective System outflow, and subvisual cirrus, Atmos. Chem. Phys., 11, 5569-5590, doi:10.5194/acp-11-55692011, 2011.

Gallagher, M. W., Connolly, P. J., Whiteway, J., Figuera-Nieto, D., Flynn, M., Choularton, T. W., Bower, K. N., Cook, C., Busen, R., and Hacker, J.: An overview of the microphysical structure of cirrus clouds observed during EMERALD-1, Q. J. Meteorol. Soc., 131, 1143-1169, doi:10.1256/qj.03.138, 2005.

Garrett, T. J., Gerber, H., Baumgärdner, D. G., Twohy, C. H., and Weinstock, E. M.: Small, highly reflective ice crystals in low-latitude cirrus, Geophys. Res. Lett., 30, 2132, doi:10.1029/2003GL018153, 2003.

Gayet, J. F., Crépel, O., Fournol, J. F., and Oshchepkov, S.: A new airborne polar Nephelometer for the measurements of optical and microphysical cloud properties. Part I: Theoretical design, Ann. Geophys., 15, 451-459, doi:10.1007/s00585-997-0451-1, 1997.

Gayet, J.-F., Auriol, F., Minikin, A., Ström, J., Seifert, M., R. Krejci, R., Petzold, A., Febvre, G., and Schumann, U.: Quantitative measurement of the microphysical and optical properties of cirrus clouds with four different in situ probes: Evidence of small ice crystals, Geophys. Res. Lett., 29, 2230, doi:10.1029/2001GL014342, 2002.

Gayet, J.-F., Ovarlez, J., Shcherbakov, V., Ström, J., Schumann, U., Minikin, A., Auriol, F., Petzold, A., and Monier, M.: Cirrus cloud microphysical and optical properties at southern and northern midlatitudes during the INCA experiment, J. Geophys. Res., 109, D20206, doi:10.1029/2004JD004803, 2004.

Gayet, J.-F., Mioche, G., Dörnbrack, A., Ehrlich, A., Lampert, A., and Wendisch, M.: Microphysical and optical properties of Arctic mixed-phase clouds. The 9 April 2007 case study., Atmos. Chem. Phys., 9, 6581-6595, doi:10.5194/acp-9-6581-2009, 2009.

Gayet, J.-F., Mioche, G., Shcherbakov, V., Gourbeyre, C., Busen, R., and Minikin, A.: Optical properties of pristine ice crystals in mid-latitude cirrus clouds: a case study during CIRCLE-2 exper- 
iment, Atmos. Chem. Phys., 11, 2537-2544, doi:10.5194/acp11-2537-2011, 2011.

Heymsfield, A. J.: Ice particle evolution in the anvil of a severe thunderstorm during CCOPE, J. Atmos. Sci., 43, 2463-2478, 1986.

Heymsfield, A. J.: On measurements of small ice particles in clouds, Geophys. Res. Lett., 34, L23812, doi:10.1029/2007GL030951, 2007.

Heymsfield, A. J. and Palmer, A.: Relationship for deriving thunderstorm anvil ice mass for CCOPE storm weather estimates, J. Clim. Appl. Meteorol., 25, 691-702, 1986.

Heymsfield, A. J., Miloshevich, L. M., Schmitt, C., Bansemer, A., Twohy, C., Poellot, M. R., Fridlind, A., and Gerber, H.: Homogeneous ice nucleation in subtropical and tropical convection and its influence on cirrus anvil microphysics, J. Atmos. Sci., 62, 41-64, 2005.

Heymsfield, A. J., Bansemer, A., Durden, S. L., Herman, R. L., and Bui, T. P.: Ice microphysics observations in Hurricane Humberto: Comparison with non-hurricane-generated ice cloud layers, J. Atmos. Sci., 63, 288-308, 2006.

Heymsfield, A. J., Bansemer, A., Heymsfield, G., and Fierro, A. O.: Microphysics of Maritime Tropical Convective Updrafts at Temperatures from -20 to $-60^{\circ} \mathrm{C}$, J. Atmos. Sci., 66, 3530 3562, 2009.

Hunt, W. H, Winker, D. M., Vaughan, M. A., Powell, K. A., Lucker, P. L., and Weimer, C.: CALIPSO Lidar Description and Performance Assessment, J. Atmos. Ocean Technol., 26, 1214-1228, doi:10.1175/2009JTECHA1223.1, 2009.

Isaac, G. A., Korolev, A. V., Strapp, J. W., Cober, S. G., Boudala, F. S., Marcotte, D., and Reich, V. L.: Assessing the collection efficiency of natural cloud particles impacting the Nevzorov total water content probe. AIAA 44th Aerospace Sciences Meeting and Exhibit, Reno, Nevada, 9-12 January 2006, AIAA-20061221, 2006.

Jensen, E. J., Lawson, P., Baker, B., Pilson, B., Mo, Q., Heymsfield, A. J., Bansemer, A., Bui, T. P., McGill, M., Hlavka, D., Heymsfield, G., Platnick, S., Arnold, G. T., and Tanelli, S.: On the importance of small ice crystals in tropical anvil cirrus, Atmos. Chem. Phys., 9, 5519-5537, doi:10.5194/acp-9-5519-2009, 2009.

Jourdan, O., Mioche, G., Garret, T. J., Schwarzenbock, A., Vidot, J., Xie, Y., Shcherbakov, V., Duroure, C., Yang, P., and Gayet, J.-F.: Coupling of the microphysical and optical properties of arctic clouds during the ASTAR 2004 experiment: Implications for light scattering modelling, J. Geophys. Res., 115, D23206, doi:10.1029/2010JD014016, 2010.

Knollenberg, R. G., Kelly, K., and Wilson, J. C.: Measurements of high number densities of ice crystals in the tops of tropical cumulonimbus, J. Geophys. Res., 98, 8639-8664, doi:10.1029/92JD02525, 1993.

Korolev, A. V. and Isaac, G. A.: Shattering during sampling by OAPs and HVPS, Part I: Snow particles, J. Atmos. Ocean Technol., 22, 528-543, 2005.

Korolev, A. V., Strapp, J. W., Isaac, G. A., and Emery, E.: Improved airborne hot-wire measurements of ice water content in clouds, Proceedings 15th Intl. Conf. on Clouds and Precipitation, Cancun, Mexico, Extended Abstracts Paper P13.4, (available online: http://cabernet.atmosfcu.unam.mx/ICCP-2008/), 2008.

Korolev, A. V., Emery, E. F., Strapp, J. W., Cober, S. G., Isaac, G.
A., Wasey, M., and Marcotte, D.: Small Ice Particles in Tropospheric Clouds: Fact or Artifact? Airborne Icing Instrumentation Evaluation Experiment, Bull. Am. Meteorol. Soc., 92, 967-973, doi:10.1175/2010BAMS3141.1, 2011.

Lawson, R. P.: Effects of ice particles shattering on the 2-D-S probe, Atmos. Meas. Tech., 4, 1361-1381, doi:10.5194/amt-41361-2011, 2011.

Lawson, R. P., Angus, L. G., and Heymsfield, A. J.: Cloud particle measurements in thunder storm anvils and possible weather threat to aviation, J. Aircraft, 35, 113-121, 1998.

Lawson, R. P., Baker, B. A., Schmitt, C. G., and Jensen, T. L.: In situ measurements of microphysical properties of mid-latitude and anvil cirrus and validation of satellite retrievals'. Paper no. TS 32.4, Proceedings of 30th International conference on remote sensing of environment, Honolulu, Hawaii, http://www. symposia.org/proceedings.htm, 2003.

Lawson, R. P., O'Connor, D., Zmarzly, P., Weaver, K., Baker, B. A., Mo, Q., and Jonsson, H.: The 2-D-S (Stereo) probe: Design and preliminary tests of a new airborne, high-speed, highresolution imaging probe, J. Atmos. Oceanic Technol., 23, 14621477, doi:10.1175/JTECH1927.1, 2006a.

Lawson, R. P., Baker, B., Pilson, B., and Mo, Q.: In Situ Observations of the Microphysical Properties of Wave, Cirrus, and Anvil Clouds, Part II: Cirrus Clouds, J. Atmos. Sci., 63, 3186-3203, $2006 b$.

Lawson, R. P., Jensen, E., Mitchell, D. L., Baker, B., Mo, Q., and Pilson, B.: Microphysical and radiative properties of tropical clouds investigated in TC4 and NAMMA, J. Geophys. Res., 115, D00J08, doi:10.1029/2009JD013017, 2010.

Mason, J. G., Strapp, J. W., and Chow, P.: The ice particle threat to engines in flight. 44th AIAA Aerospace Sciences Meeting, Reno, Nevada, 9-12 January 2006, AIAA-2006-206, 2006.

Mazzawy, R. S. and Strapp, J. W.: Appendix D - An Interim Icing Envelope: High Ice Crystal Concentrations and Glaciated Conditions, 2007 SAE Aircraft and Engine Icing International Conference, doi:10.4271/2007-01-3311, 2007.

McFarquhar, G. M. and Heymsfield, A. J.: Microphysical characteristics of three anvils sampled during the Central Equatorial Pacific Experiment, J. Atmos. Sci., 53, 2401-2423, doi:10.1175/1520-0469(1996)053<2401:MCOTAS > 2.0.CO;2., 1996.

McFarquhar, G., Zhang, G., Poellot, M. R., Kok, G. L., McCoy, R., Tooman, T., Fridlind, A., and Heymsfield, A.: Ice properties of single-layer stratocumulus during the Mixed-Phase Arctic Cloud Experiment, 1. Observations, J. Geophys. Res., 112, D24201, doi:10.1029/2007JD008633, 2007.

McNaughtan, I. I.: The analysis of measurements of free ice and ice/water concentrations in the atmosphere of the equatorial zone. Royal Aircraft Establishment (Farnbor-ough) Technical Note No., Mech. Eng., 283, 1959.

Mishchenko, M. I. and Sassen, K.: Depolarization of lidar returns by small ice crystals: An application to contrails, Geophys. Res. Lett., 25, 309-312, doi:10.1029/97GL03764, 1998.

Mioche, G., Josset, D., Gayet, J.-F., Pelon, J., Garnier, A., Minikin, A., and Schwarzenboeck, A.: Validation of the CALIPSO/CALIOP extinction coefficients from in situ observations in mid-latitude cirrus clouds during CIRCLE-2 experiment, J. Geophys. Res., 115, D00H25, doi:10.1029/2009JD012376, 2010a. 
Mioche G.: Validation des produits d'inversion des observations satellitaires CALIPSO et CloudSat pour la caractérisation des propriétés optiques et microphysiques des nuages de glace et en phase mixte, Thèse de l'Université Blaise Pascal (Mars 2010), 212 pp., 2010 b.

Mitchell, D. L., Zhang, R., and Pitter, R. L.: Mass-dimensional relationships for ice particles and the influence of riming on snowfall rates, J. Appl. Meteorol., 29, 153-163, 1990.

Platt, C. M. R., Vaughan, M. A., and Austin, R. T.: Characteristics of CALIPSO and CloudSat Backscatter at the Top Center Layers of Mesoscale Convective Systems and Relation to Cloud Microphysics, J. Appl. Meteorol. Clim., 50, 368-378, 2011.

Protat, A., Pelon, J., Testud, J., Grand, N., Delville, P., Laborie, P., Vinson, J. -P., Bouniol, D., Bruneau, D., Chepfer, H., Delanoë , J., Haeffelin, M., Noël, V., and Tinel, C.: Le projet RALI: Combinaison d'un radar nuage et d'un lidar pour l'étude des nuages faiblement précipitants, La Météorologie, 8e série, 47, 23-33, 2004.

Protat, A., Delanoë, J., Bouniol, D., Heymsfield, A. J., Bansemer, A., and Brown, P.: Evaluation of ice water content retrievals from cloud radar reflectivity and temperature using a large airborne in situ microphysical database, J. Appl. Meteorol. Clim., 46, 557572, 2007.

Protat, A., Bouniol, D., Delanoë, J., O'Connor, E., May, P. T., Plana-Flattori, A., Hasson, A., Görsdorf, U., and Heymsfield, A. J.: Assessment of Cloudsat Reflectivity measurements and ice cloud properties using ground-based and airborne cloud radar observations, J. Atmos. Ocean. Technol., 26, 1717-1741, 2009.

Protat, A., McFarquhar, G., Um, J., and Delanoë, J.: Obtaining best estimates for the micro physical and radiative properties of tropical ice clouds from TWP-ICE in-situ microphysical observations, J. Appl. Meteor. Clim., 50, 895-915, doi:10.1175/2010JAMC2401.1, 2010.

Sassen, K. and Zhu, J.: A global survey of CALIPSO linear depolarization ratios in ice clouds: Initial findings, J. Geophys. Res., 114, D00H07, doi:10.1029/2009JD012279, 2009.

Sassen, K., Comstock, J. M., Wang, Z., and Mace, G.: Cloud and aerosol research capabilities at FARS: The facility for atmospheric remote sensing, Bull. Am. Meteorol. Soc., 82, 11191138, 2001.

Saunders, C. P. R. and Wahab, N. M. A.: The influence of electric fields on the aggregation of ice crystals, J. Meteorol. Soc. Jpn., 53, 121-126, 1975.

Sayres, D. S., Smith, J. B., Pittman, J. V., Weinstock, E. M., Anderson, J. G., Heymsfield, G., Li, L., Fridlind, M., and Ackerman, A. S.: Validation and determination of ice water content-radar reflectivity relationships during CRYSTAL-FACE: Flight requirements for future comparisons, J. Geophys. Res., 113, D05208, doi:10.1029/2007JD008847, 2008.
Shcherbakov, V., Gayet, J.-F., Jourdan, O., Minikin, A., Ström, J., and Petzold, A.: Assessment of cirrus cloud optical and microphysical data reliability by applying statistical procedures, J. Atmos. Oceanic. Technol., 22, 409-420, 2005.

Sherwood, S. C., Phillips, V. T. J., and Wettlaufer, J. S.: Small ice crystals and the climatology of lightning, Geophys. Res. Lett., 33, L05804, doi:10.1029/2005GL025242, 2006.

Stephens, G. L., Tsay, S. C., Stackhouse, P. W., and Flatau, P. J.: The relevance of the microphysical and radiative properties of cirrus clouds to climate and climatic feedback, J. Atmos. Sci., 47, 1742-1753, doi:10.1175/1520-0469, 1990.

Stephens, G. L., Vane, D.G., Boain, R. J., Mace, G. G., Sassen, K., Wang, Z., Illingworth, A. J., O’Connor, E. J., Rossow, W. B., Durden, S. L., Miller, S. D., Austin, R. T., Benedetti, A., Mitrescu, C., and CloudSat Science Team: The CloudSat mission and the A-TRAIN: A new dimension to space-based observations of clouds and precipitation, Bull. Am. Meteorol. Soc., 83, 17711790, 2002.

Stith, J. L., Dye, J., Bansemer, A., Heymsfield, A. J., Grainger, C. A., Petersen, W. A., and Ciffelli, R.: Microphysical observations of tropical clouds, J. Appl. Meteorol., 41, 97-117, 2002.

Strapp, J. W., Chow, P., Maltby, M., Bezer, A. D., Korolev, A., Stromberg, I., and Hallett, J.: Cloud microphysical measurements in thunderstorm outflow regions during Allied/BAe 1997 flight trials, 37th AIAA Aerospace Sciences Meeting and Exhibit, Reno, NV., 11-14 Jan 1999, AIAA 99-0498, 1999.

Wahab, N. M. A.: Ice crystal interactions in electric fields, PhD thesis, UMIST, 1974.

Winker, D. M., Pelon, J., and McCormick, M. P.: The CALIPSO mission: Spaceborne lidar for observation of aerosols and clouds, Status and Performance, Proceedings of SPIE, 4893, 1-11, 2003.

Winker, D. M., Pelon, J., Coakley Jr., J. A., Ackerman, S. A., Charlson, R. J., Colarco, P. R., Flamant, P., Fu, Q., Hoff, R., Kittaka, C., Kubar, T. L., LeTreut, H., McCormick, M. P., Megie, G., Poole, L., Powell, K., Trepte, C., Vaughan, M. A., Wielicki, B. A.: The CALIPSO Mission: A Global 3-D View Of Aerosols And Clouds, Bull. Am. Meteorol. Soc., 91, 1211-1229, doi:10.1175/2010BAMS3009.1, 2010.

Wirth, M., Fix, A., Mahnke, P., Schwarzer, H., Schrandt, F., and Ehret, G.: The airborne multi-wavelength water vapor differential absorption lidar WALES: system design and performance, Appl. Phys. B, 96, 201-213, doi:10.1007/s00340-009-3365-7, 2009. 